\title{
ALGILANAN HİZMET KALİTESİNIN MÜŞTERİ MEMNUNİYETİ VE SADAKATİNE ETKİSİ: YİYECEK-İÇECEK SEKTÖRÜNDE NİCEL BİR ARAŞTIRMA ${ }^{1}$
}

Elif KOCAGÖZ 2

Ahmet Melih EYİTMiş ${ }^{3}$
Received Date (Başvuru Tarihi):

Accepted Date (Kabul Tarihi):

Published Date (Yayın Tarihi):
$16 / 11 / 2020$

$18 / 12 / 2020$

$25 / 12 / 2020$

Çalıșmada ilk yazar Sorumlu Yazar (Corresponding Author) rolündedir.

$\ddot{O Z Z}$

\section{Anahtar Kelimeler:}

Hizmet Kalitesi,

Müşteri Memnuniyeti,

Müşsteri Sadakati,

Yeme-İçme İşletmeleri

JEL Kodlar:

M31,

L83,

Z31

Keywords:

Perceived Service
Quality

Yiyecek-içecek sektörü rekabet yoğun bir sektör olup, bu sektörde müşteri memnuniyetini sağlamak ve müşteri sadakatini kazanmak gün geçtikçe zorlaşmaktadır. Müşteri memnuniyeti ve sadakati, işletmenin sunduğu hizmetlerin kalitesiyle ilgili iki kavram olup, müşterilerin aldıkları hizmetin kalitesine yönelik algıları hem memnuniyetlerini hem de sadakatlerini etkileyebilmektedir. Bu çalışmanın amacı algılanan hizmet kalitesinin ve alt boyutlarnın hem müşteri memnuniyetine hem de sadakatine ne düzeyde etki ettiğini incelemektir. Nicel araştırma yöntemlerinden anket yöntemiyle yapılan araştırma, ulusal bir kahve zinciri şubesinin 524 müşterisi ile gerçekleştirilmiştir. Araştırma katılımcılarının işletmenin hizmet kalitesine yönelik algılarının müşteri memnuniyetini ve sadakatini pozitif yönde anlamlı etkilediği, müşteri memnuniyetinin de sadakati benzer şekilde pozitif yönde anlaml etkilediği bulunmuştur. Ancak bă̆ımsız değişken hizmet kalitesi ile, müşteri sadakati bă̆ımlı değişkeninde açıklanan varyansın müşteri memnuniyeti bağıml değişkeninde açıklanan varyanstan daha az olduğu görülmüştür. Çalışmada katılımcların hizmet kalitesi algılarını, memnuniyet düzeylerinin ve sadakat durumlarının demografik değişkenler itibariyle farklılık gösterip göstermediŏine yönelik ilave incelemeler de yapılmış, cinsiyet, çalışma durumu ve gelir değişkenleri itibariyle katılımcıların bazı yanıtlarında anlamlı farklılıklar olduğu görülmüştür. Ayrıca müdavim müşterilerin kalite algılarının, memnuniyetlerinin ve sadakatlerinin diğer müşterilere kıyasla anlamlı olarak yüksek olduğu bulunmuştur.

JEL Codes:
Customer Satisfaction

Customer Loyalty
Food and Beverage Enterprises
M31
L83

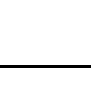

\footnotetext{
${ }^{1}$ Bu çalışma “Hizmet Kalitesinin Müşteri Memnuniyetine ve Sadakatine Etkisi: Ulusal Bir Kahve Zincirinin Kahramanmaraş Şubesinde Nicel Bir Araştırma" başlığıyla 12-13 Aralık 2020 tarihlerinde düzenlenen International Conference on Empirical Economics and Social Sciences (e-ICEESS'20) kongresinde sözlü bildiri olarak sunulmuştur.

${ }^{2}$ Dr. Öğr. Üyesi, Kahramanmaraş Sütçü İmam Üniversitesi, elifsayin@yahoo.com, https://orcid.org/0000-0001-9575-1664

${ }^{3}$ Dr. Öğr. Üyesi, Kahramanmaraş Sütçü İmam Üniversitesi, a_melih@hotmail.com, https://orcid.org/0000-0003-1236-7689
} 


\section{EXTENDED ABSTRACT}

\section{THE EFFECTS OF PERCEIVED SERVICE QUALITY ON CUSTOMER SATISFACTION AND LOYALTY: A QUANTITATIVE RESEARCH IN THE FOOD AND BEVERAGE INDUSTRY}

\section{LITERATURE}

\subsection{RESEARCH SUBJECT}

The food and beverage industry is highly competitive, and it is getting increasingly more challenging to ensure customer satisfaction, to create loyalty, and to maintain them (Tuncer, 2017; Aksu, Korkmaz ve Sünnetçioğlu, 2016; Chen, 2012). Both are related to the quality of the services offered by the business. Customers' perceptions of service quality can affect both their satisfaction and loyalty. Studies show that an increase in the service quality of the businesses brings along an increase in customer satisfaction, customer loyalty and customers' intention to recommend the company. In both international and Turkish literature, it is seen that both customer satisfaction and customer loyalty in the food and beverage industry are closely related to the service quality (Yanginlar and Tuna, 2020; Bilgin, 2017; Chen, 2016; Aksu et al., 2016; İlhan and Kılıçhan, 2016; Diab, Mohammed, Mansour and Saad, 2016; Bekar and Kılıç, 2015; Haghigi, Dorosti, Rahnama and Hoseinpour, 2012; Barber, Goodman and Goh, 2011; Hyun, 2010; Bulgan, 2010; Ha and Jang, 2010; Kim, Ng and Kim, 2009; Andaleeb and Conway, 2006).

Service quality is defined as the customer's evaluation of the services provided by the business, and the actual service quality is being explained by the difference between the customers' expectations regarding the quality of the service provided and their perceptions of the quality of the service they received (Kırcova, Köse and Özer, 2020, p. 81-82; Martinez and Martinez, 2010, p. 30; Parasuraman, Zeithaml and Berry, 1985, p. 42-47). Various scales are measuring the service quality in food and beverage enterprises, and most of them were developed based on Parasuraman's five-dimensional SERVQUAL scale (Parasuraman, Zeithaml and Berry, 1988). One of them is the DINESERV scale. This scale was designed in five dimensions by adapting and reproducing the items of SERVQUAL and LODGESERV scales (Tuncer, 2017, p. 325-326; Hansen, 2014, p. 120; Stevens, Knutson and Patton, 1995). DINESERV is defined as a quality measurement method developed to measure the quality of the service provided in food and beverage establishments (Kılıç ve Kurnaz, 2019, p. 92) and because of the ease and reliability of the scale (Kılıçhan and Ülker, 2015, p. 887), researchers in current studies frequently use it. For example, the DINESERV scale was used in Chun and Nyam-Ochir's study (2020) examining the effects of customer satisfaction on revisiting the same restaurant chain and recommendation behaviour; in Adeinat's study (2019) investigating the service quality perceptions of the customers of three restaurants operating under the same franchising brand; in Kim and Choi's study (2019) revealing the differences between the service standards of managers in all-you-can-eat restaurants and the quality perceptions of the customers.

The dimensions of the service quality within the framework of the DINESERV scale are as follows (Stevens et al., 1995): Tangibles: Tools and equipment used in the provision of services of food and beverage enterprises, personnel (appearance), the place where the service is provided, and other physical elements. Reliability: The ability to fulfil the promise (e.g. orders) reliably and accurately in the services provided. Responsiveness: Willingness to assist the customers to whom the service is provided and to fulfil the service in a fast and punctual manner. Assurance: Knowledgeable service providers/employees who have information about the service provided (e.g. menus, the way meals are made, the materials used), employees' courtesy towards customers and their ability to create trust in them. Empathy: Placing the customer at the centre of the company's services, taking care of them.

Other constructs of this study are customer satisfaction and customer loyalty. Customer satisfaction refers to the state of happiness or pleasure that the customer will experience when the quality perception of the product/service is equal to or above his/her expectations as a result of appropriately fulfilled demands and requests (Kurnuç, Kurucuk and Küçük, 2015, p. 24). Customer loyalty as a concept includes several behavioural, emotional, attitudinal constructs (Küçükergin and 
Uygur, 2013; Kumar and Shah, 2004; Chaudhuri and Holbrook, 2001) and it refers to the behaviour and feeling of customers to continue to purchase the product/service from the same place and to be a regular customer of the business.

\subsection{RESEARCH PURPOSE AND IMPORTANCE}

The purpose of this study is to examine to what extent perceived service quality, and in particular, the quality perceptions at five dimensions of the services, affect both customer satisfaction and loyalty, and also to determine the extent to which customer satisfaction explains customer loyalty, at a branch of a national coffee chain operating in the food and beverage industry. The study also aimed to examine whether customers' perceptions of service quality, their satisfaction and loyalty differ significantly between groups in terms of demographic variables, visiting frequency and purpose of visiting the branch. Wilson, Zeithaml, Bitner and Gremler (2016) underline that the service performance is an issue that needs to be monitored continuously due to the heterogeneity of services/employees. This research is the first comprehensive quality measurement at the mentioned branch. Therefore, from the managerial perspective, the study is thought to be useful and beneficial by revealing branch customers' service quality perceptions in general and in each dimension, and finding out how they affect their satisfaction levels and loyalties.

\subsection{CONTRIBUTION of the ARTICLE to the LITERATURE}

Since there are no visible studies in the Turkish literature regarding service quality specific to coffee chains as it is examined within the scope of this study, the current study is expected to contribute to the related literature.

\section{DESIGN and METHOD}

\subsection{RESEARCH TYPE}

Survey method, one of the quantitative research methods, was used in this study.

\subsection{RESEARCH PROBLEMS}

Following research questions are being answered in this study: Does perceived service quality have impacts on customer satisfaction and loyalty at the company in question? How much of the variances in customer satisfaction and loyalty are being explained by the perceived service quality? Which dimensions of the service quality affect customer satisfaction and loyalty? Do customers' perceptions on service quality, satisfaction levels and loyalties differ in terms of demographic variables, visiting frequency and visiting purpose?

\subsection{DATA COLLECTION METHOD}

The population of the study consists of customers visiting the Kahramanmaras branch of a national coffee chain. Permissions were obtained from the enterprise before conducting the research. The data was collected by using convenience sampling between 14th and 20th of December 2019. The research was carried out by conducting questionnaires face-to-face to 551 customers inside the branch between the hours of 10:00 and 24:00. Twenty-seven questionnaire forms were invalid. The data obtained from 524 questionnaires were accepted for further analysis.

The questionnaire form used in the study comprises of three parts. In the first part, there are questions on demographic characteristics of the research participants, the visiting frequency of them and their purposes of visiting this branch like drinking coffee, socializing, seeking tranquillity. The second part of the questionnaire includes the DINESERV scale developed by Stevens et al. (1995). The reliability of the scale has been tested (Cronbach's alpha: 0.98). Since the dimensions of the scale are settled in the literature, in order not to disrupt the scientific structure of the scale, reliability analyses were performed for each dimension, namely approaching them as a single construct (Tangibles Cronbach's alpha: 0.90; Reliability Cronbach's alpha: 0.89; Responsiveness Cronbach's alpha: 0.87; Assurance Cronbach's alpha: 0.94; Empathy Cronbach's alpha: 0.94). The third part of the questionnaire includes a seven-item customer satisfaction scale (Cronbach's alpha: 0,90) and a four-item customer loyalty scale (Cronbach's alpha: 0,78 ) both developed by the researchers. 


\subsection{QUANTITATIVE ANALYSIS}

Following analyses were made by using statistical program SPSS: Reliability test, regression analysis, independent samples $t$-test, ANOVA and Scheffe and Tukey-Kramer Post Hoc tests.

\subsection{RESEARCH HYPOTHESES}

$\mathbf{H}_{1}$ : Perceived service quality positively affect customer satisfaction.

$\mathbf{H}_{1 \mathbf{a}}$ : Quality perception of tangibles positively affect customer satisfaction.

$\mathbf{H}_{1 \mathbf{b}}$ : Quality perception of reliability positively affect customer satisfaction.

$\mathbf{H}_{1 \mathbf{c}}$ : Quality perception of responsiveness positively affect customer satisfaction.

$\mathbf{H}_{1 \mathrm{~d}}$ : Quality perception of assurance positively affect customer satisfaction.

$\mathbf{H}_{1 \mathrm{e}}$ : Quality perception of empathy positively affect customer satisfaction.

$\mathbf{H}_{2}$ : Perceived service quality positively affect customer loyalty.

$\mathbf{H}_{2 \mathrm{a}}$ : Quality perception of tangibles positively affect customer loyalty.

$\mathbf{H}_{2 \mathrm{~b}}$ : Quality perception of reliability positively affect customer loyalty.

$\mathbf{H}_{2 \mathbf{c}}$ : Quality perception of responsiveness positively affect customer loyalty

$\mathbf{H}_{\mathbf{2 d}}$ : Quality perception of assurance positively affect customer loyalty.

$\mathbf{H}_{2 \mathrm{e}}$ : Quality perception of empathy positively affect customer loyalty.

$\mathbf{H}_{3}$ : Customer satisfaction positively affects customer loyalty.

$\mathbf{H}_{4}$ : Perceived service quality $\left(\mathrm{H}_{4 a}\right)$, customer satisfaction $\left(\mathrm{H}_{4 \mathrm{~b}}\right)$ and customer loyalty $\left(\mathrm{H}_{4 \mathrm{c}}\right)$ differ significantly between groups in terms of gender.

$\mathbf{H}_{5}$ : Perceived service quality $\left(\mathrm{H}_{5 \mathrm{a}}\right)$, customer satisfaction $\left(\mathrm{H}_{5 \mathrm{~b}}\right)$ and customer loyalty $\left(\mathrm{H}_{5 c}\right)$ differ significantly between groups in terms of marital status.

$\mathbf{H}_{6}$ : Perceived service quality $\left(\mathrm{H}_{6 \mathrm{a}}\right)$, customer satisfaction $\left(\mathrm{H}_{6 \mathrm{~b}}\right)$ and customer loyalty $\left(\mathrm{H}_{6 c}\right)$ differ significantly between groups in terms of education.

$\mathbf{H}_{7}$ : Perceived service quality $\left(\mathrm{H}_{7 \mathrm{a}}\right)$, customer satisfaction $\left(\mathrm{H}_{7 \mathrm{~b}}\right)$ and customer loyalty $\left(\mathrm{H}_{7 \mathrm{c}}\right)$ differ significantly between groups in terms of employment status.

$\mathbf{H}_{8}$ : Perceived service quality $\left(\mathrm{H}_{8 \mathrm{a}}\right)$, customer satisfaction $\left(\mathrm{H}_{8 \mathrm{~b}}\right)$ and customer loyalty $\left(\mathrm{H}_{8 c}\right)$ differ significantly between groups in terms of income.

$\mathbf{H}_{9}$ : Perceived service quality $\left(\mathrm{H}_{9 a}\right)$, customer satisfaction $\left(\mathrm{H}_{9 b}\right)$ and customer loyalty $\left(\mathrm{H}_{9 c}\right)$ differ significantly between groups in terms of visiting frequency.

$\mathbf{H}_{10}$ : Perceived service quality $\left(\mathrm{H}_{100}\right)$, customer satisfaction $\left(\mathrm{H}_{10 \mathrm{~b}}\right)$ and customer loyalty $\left(\mathrm{H}_{10 \mathrm{c}}\right)$ differ significantly between groups in terms of visiting purpose.

\section{FINDINGS and DISCUSSION}

\subsection{FINDINGS as a RESULT of ANALYSIS}

The means of the scales are as follows: Perceived service quality scale's mean $\bar{X}=5.53$ (SD: 1.23), customer satisfaction scale's mean $\bar{X}=5.63$ (SD: 1.26) and customer loyalty scale's mean $\bar{X}=5.40$ (SD: 1.40). In the dimensions of service quality, following means were observed: $\bar{X}=5.73$ (SD: 1.26) for reliability, $\bar{X}=5.53$ (SD: 1.49 ) for responsiveness, $\bar{X}=5.52$ (SD: 1.37) for assurance, $\bar{X}=5.45$ (SD: 1.16) for tangibles and: $\bar{X}=5.44$ (SD: 1.49 ) for empathy.

Regression analysis results: [No multicollinearity problem detected for the multiple regression models.] Perceived service quality significantly and positively affects customer satisfaction $\left(\beta=0,781, R^{2}\right.$ : $0,61, p<0.05)$. Service quality perceptions at the dimensions tangibles $(\beta=0,343)$, assurance $(\beta=0,140)$ and empathy $(\beta=0,235)$ significantly and positively affect customer satisfaction $(\mathrm{p}<0.05)$. Perceived service quality significantly and positively affects customer loyalty $\left(\beta=0,654, R^{2}: 0,43 . p<0.05\right)$. Quality perceptions at the dimensions tangibles $(\beta=0,316)$, reliability $(\beta=0,147)$, and empathy $(\beta=0,245)$ 
significantly and positively affect customer loyalty $(\mathrm{p}<0.05)$. Customer satisfaction significantly and positively affects customer loyalty $\left(\beta=0,758, R^{2}: 0,57, p<0.05\right)$.

Independent samples $t$-test results: The perception of service quality was significantly higher in women $(\bar{X}: 5.67)$ compared to men $(\bar{X}: 5.41)[p<0.05]$. There were no significant differences between these groups regarding customer satisfaction and loyalty. In terms of marital status, there were also no significant differences between groups in service quality perception, customer satisfaction and loyalty.

ANOVA and Post Hoc tests results: There were no significant differences between groups in terms of education level regarding service quality perception, customer satisfaction and loyalty. There was also no significant difference between the groups in the perceptions of service quality in terms of employment status; but both satisfaction $(\bar{X}: 5,52)$ and loyalty $(\bar{X}: 5,24)$ of the students' group were lower than the participants who own their businesses, i.e. entrepreneurs [in customer satisfaction, mean difference: $-0,42577$, Sig.: 0,07; in customer loyalty, mean difference: $-0,53357$, Sig.: 0,03]. In terms of income, there were significant differences between the groups in service quality perception, customer satisfaction and loyalty. Those who have higher incomes (5001 TL and more) have higher service quality perceptions $(\bar{X}: 5,85)$ compared to lower-income group 2 (2500 TL and less) [mean difference: 0,53108 , Sig.: 0,00]. Those who have higher incomes (5001 TL and more) are more satisfied $(\bar{X}: 6,05)$ compared to lower-income group 1 (2501-5000 TL) [mean difference: 0,46136, Sig.: 0,03] and lower-income group 2 [mean difference: 0,60321 , Sig.: 0,00]. The loyalty is also stronger at the higher income group (5001 TL and more) $(\bar{X}: 5,67)$ compared to lower-income group 2 [mean difference: 0,44070, Sig.: 0,03]. In terms of visiting frequency, there were significant differences between the groups regarding service quality perception, customer satisfaction and loyalty. Regulars' service quality perception $(\bar{X}: 5,88)$ was significantly higher compared to first-time visitors of the branch [mean difference: 0,71773 , Sig.: 0,02] and to the participants who have previously visited the place at least once -but not regulars- [mean difference: 0,60586 , Sig.: 0,00]. Regulars are also more satisfied $(\bar{X}: 5,98)$ compared to first-time visitors [mean difference: 0,99653 , Sig.: 0,00 ] and to those who are not regulars [mean difference: 0,56479 , Sig.: $0,00]$. Loyalty is stronger at regulars $(\bar{X}: 5,85)$, compared to both first-time visitors [mean difference: 1,44111, Sig.: 0,00] and to those who are not regulars [mean difference: 0,70483, Sig.: 0,00]. Loyalty is also stronger at the customers who are not regulars $(\bar{X}: 5,14)$ compared to first-time visitors [mean difference: 0,73628, Sig.: 0,00]. Lastly, no significant differences were found between groups in terms of visiting purpose in service quality perception, satisfaction and loyalty.

\subsection{HYPOTHESIS TEST RESULTS}

Hypetheses $\mathrm{H}_{1}, \mathrm{H}_{1 \mathrm{a}}, \mathrm{H}_{1 \mathrm{~d}}, \mathrm{H}_{1 \mathrm{e}}, \mathrm{H}_{2}, \mathrm{H}_{2 \mathrm{a}}, \mathrm{H}_{2 \mathrm{~b}}, \mathrm{H}_{2 \mathrm{e}}, \mathrm{H}_{3}, \mathrm{H}_{4 a}, \mathrm{H}_{7 \mathrm{~b}}, \mathrm{H}_{7 \mathrm{c}}, \mathrm{H}_{8 \mathrm{a}}, \mathrm{H}_{8 \mathrm{~b}}, \mathrm{H}_{8 \mathrm{c}}, \mathrm{H}_{9 \mathrm{a}}, \mathrm{H}_{9 \mathrm{~b}}$ and $\mathrm{H}_{9 c}$ were accepted and hypotheses $\mathrm{H}_{1 \mathrm{~b}}, \mathrm{H}_{1 \mathrm{c}}, \mathrm{H}_{2 \mathrm{c}}, \mathrm{H}_{2 \mathrm{~d}}, \mathrm{H}_{4 \mathrm{~b}}, \mathrm{H}_{4 c}, \mathrm{H}_{5 a}, \mathrm{H}_{5 \mathrm{~b}}, \mathrm{H}_{5 c}, \mathrm{H}_{6 \mathrm{a}}, \mathrm{H}_{6 \mathrm{~b}}, \mathrm{H}_{6 c}, \mathrm{H}_{7 \mathrm{a}}, \mathrm{H}_{10 \mathrm{a}}, \mathrm{H}_{10 \mathrm{~b}}$ and $\mathrm{H}_{10 \mathrm{c}}$ were rejected.

\subsection{DISCUSSING the FINDINGS with the LITERATURE}

The service quality perceptions of the research participants significantly and positively affect both customer satisfaction and loyalty. These findings seem to be consistent with the literature (Bilgin, 2017; Aksu et al. 2016; Diab et al., 2016; Bekar and K1lıç, 2015; Haghigi et al., 2012; Ha and Jang, 2010). In terms of the dimensions of service quality, it was found that quality perceptions of tangibles, assurance and empathy dimensions positively affect both customer satisfaction and customer loyalty, while the effects of reliability and responsiveness were statistically not significant. Findings on the effects of the dimensions of the service quality on customer satisfaction and/or loyalty or findings on the relative importance of the dimensions of the service quality vary in the literature (Chen, 2016; Aksu et al., 2016; Andaleeb and Conway, 2006). These differences in the literature are thought to be natural due to the differentiation of the quality of the services provided by the companies in question. Customer perceptions regarding service elements may naturally differ in each research unit.

\section{CONCLUSION, RECOMMENDATION AND LIMITATIONS}

\subsection{RESULTS of the ARTICLE}

The service quality perceptions of the research participants significantly and positively affect both customer satisfaction and loyalty. However, it was observed that the variance explained in customer satisfaction was higher than the variance explained in customer loyalty. In terms of the dimensions of service quality, it was found that tangibles, assurance and empathy dimensions 
positively affect both customer satisfaction and customer loyalty, while the effects of reliability and responsiveness were statistically not significant. Additional analyses were made in order to reveal whether the service quality perceptions, satisfaction levels and loyalties of the participants differ in terms of demographic variables. It was found that the perception of service quality was significantly higher in women compared to men, and there were no significant differences between these groups regarding customer satisfaction and loyalty. There was also no significant difference between the groups in the perceptions of service quality in terms of employment status, but both satisfaction and loyalty of the participants who own their businesses e.g. entrepreneurs were higher than the student segment. Additionally, those who have higher incomes have higher service quality perceptions, as well as satisfaction and loyalty, compared to those with lower incomes. It was also found that the evaluations of the regulars regarding service quality, satisfaction and loyalty were significantly positive than the other two groups, i.e. first-time visitors and those who have previously visited the place at least once. Lastly, in the service quality perception, satisfaction and loyalty, no significant differences were found between the groups in terms of visiting purpose, i.e. socializing, eating\&drinking and seeking tranquility\&wanting to be alone.

\subsection{SUGGESTIONS BASED on RESULTS}

Although the service quality perceptions of the participants were high in all groups, the finding that those perceptions explain participants' loyalty less than their satisfaction is thought to be important. Here, it is necessary for this enterprise to determine other explanatory variables of loyalty and to consider them for further decisions. The branch in question will also need to evaluate and examine the reasons for the differences in responses of the participants in terms of some demographic variables. More importantly, there is a necessity for evaluating the results in terms of the dimensions of service quality. As Hansen (2014, p. 120) stated, metrics such as DINESERV provide information to the owners and managers about the service quality of their businesses and give them an idea about the steps to be taken. For this reason, based on the result that customers' quality perceptions on tangibles, assurance and empathy affect their satisfaction and loyalty, the company must provide a sustainable quality on these three dimensions. On the other hand, the branch must also work on reliability and responsiveness dimensions, review the elements of them and ensure a new design that will provide better quality and as a result will affect customers' satisfaction and loyalty. As Wilson et al. (2016) underline, service performance is an issue that needs to be monitored continuously due to the heterogeneity of services/employees. Kurcova et al. (2020, p. 81) also emphasize the difficulty of providing the services, in the same way, every time. Therefore, the branch should monitor service quality in each dimension through systematic studies rather than one-off measurements and should regularly review and accordingly reshape managerial decisions and practices. Lastly, the regulars' perceptions of service quality and their satisfaction levels were significantly higher than the other groups. Did this group scored more positively because they are loyal customers, and the loyal customers tend not to see service failures and tend to forgive the mistakes (Yagil and Luria, 2016; Armağan and Acayip, 2015) or are they loyal customers because they previously had and are still having positive experiences? These questions must be answered since the latter could be evaluated as a favourable situation, while the former does not always guarantee that the company is entirely successful. As Villi stated $(2019$, p. 60), it is not possible to be utterly faultless in the service sector. Customers' loyalty is also not always completely steady. Therefore, in order to keep regulars loyal and also gain new loyal customers, the company must focus on the sustainability of the quality of the services.

\subsection{LIMITATIONS of the ARTICLE}

The study has a methodological limitation that may directly affect the interpretation of the research findings. The research was conducted within the branch while customers were experiencing the services. The averages of the answers given by the participants to all variables mentioned above were above five on a 7-point scale. Were these favourable results obtained under the effects of some variables which were not methodologically considered at this research? Did the existence of the employees during the data collection process or experiencing the service elements while answering the questions affect the answers? Could being already there at the branch on own will be considered as a sign of customer's preference with positive feelings towards the place and therefore, the answers are accordingly relatively positive? Did research affect the way the company served to the customers since the employees were aware of the research process? These are not clear in this study. Further researches 
can focus on two different samples, i.e. customers who are experiencing the services during the data collection process, namely inside the branch and customers reached outside the branch. A clearer view could be obtained with such research design that eliminates some factors affecting the interpretation of the results and can lead to a better understanding of the issue in question. Lastly, customer satisfaction could be an intermediary variable between perceived service quality and customer loyalty. This concept was out of this research scope. For further studies, intermediation could also be considered while developing research models. 


\section{GİRIŞ}

Yiyecek-içecek sektörü rekabet yoğun bir sektör olup, bu sektörde müşteri memnuniyetini sağlamak ve sadakat oluşturmak ve bunları korumak gün geçtikçe zorlaşmaktadır (Tuncer, 2017; Aksu, Korkmaz ve Sünnetçioğlu, 2016; Chen, 2012). Bir yandan tüketicilerin sürekli yeni deneyimler araması, diğer yandan dışarıda yemek yeme/eve sipariş verme talebinde gözlenen artış, diğer yandan yeme-içmenin biyolojik/fizyolojik bir ihtiyaç çerçevesinin ötesine geçip psikolojik, sosyal ve kültürel birer eylem olarak sosyalleşme, paylaşma, eğlenme, gösterme vb. çoklu ihtiyaçların karşılandığı bir hizmet alanına dönüşmesi ve tüm bu ihtiyaçları çeşitli düzeylerde karşılayan bir çok işletmenin varlığı yeme-içme sektörünü son derece dinamik bir alan olarak şekillendirmektedir. Bu dinamizm içerisinde, müşteri memnuniyeti ve sadakatini oluşturup koruyabilmek giderek güçleşmektedir.

Yiyecek-içecek işletmelerinde müşterilerin memnuniyetini yüksek seviyede tutmak ve sadakatini kazanmak, rekabette üstünlük elde edebilmek ve iş sürdürülebilirliğini sağlayabilmek adına hizmet kalitesi kesinlikle göz ardı edilemeyecek bir konudur (Aydoğdu, Yaşarsoy ve Dilsiz, 2019, s. 157). Müşteri memnuniyeti ve sadakati, hizmet kalitesiyle doğrudan ilişkili olup, sunulan hizmetlerdeki kaliteye yönelik müşterilerin algıları hem memnuniyetlerini hem de sadakatlerini etkileyebilmekte; memnuniyet de sadakatin oluşmasında öncül olabilmektedir. Çalışmalar yeme-içme sektöründe bulunan işletmelerin hizmet kalite düzeylerindeki artışın, müşteri memnuniyetinde, müşteri sadakatinde ve işletmeyi önerme eğilimlerinde artışı da beraberinde getirdiğini göstermektedir (Chen, 2016; Hyun, 2010; Kim, Ng ve Kim, 2009). Bu çalışmanın amacı yeme-içme sektöründe faaliyette bulunan ulusal bir kahve zinciri şubesinde müşterilerin algıladıkları hizmet kalitesinin müşteri memnuniyeti ve müşteri sadakati üzerine etkisini ve müşteri memnuniyetinin de müşteri sadakatinin ne kadarını açıkladığını incelemektir. Çalışma söz konusu kahve zincirinin ilgili şubesinde yapılan ilk sistematik çok boyutlu hizmet kalitesi ölçümü olarak öneme sahiptir. Ayrıca Türkçe literatürde görülebildiği kadarıyla kahve zincirleri özelinde hizmet kalitesinin bu çalışmanın kapsamında incelendiği çalışma bulunmamaktadır, dolayısıyla çalışmanın ilgili literatüre katkıda bulunabileceği düşünülmektedir. 


\section{KAVRAMSAL ÇERÇEVE}

Hizmet kavram olarak, değişim sonucunda somut bir çıktı olmayan ve üretildiği andan itibaren tüketime dönüşen; müşteriye rahatlık, zaman, uygunluk açısından bir yarar sağlayan; ister insan tarafından isterse teknolojik araçların vasıtasıyla gerçekleştirilsin ihtiyaçları gidermek üzere yürütülen ekonomik faaliyetlerin tümüdür (Bayuk, 2006, s. 2). Hizmet kalitesi ise, müşterinin tercih ettiği işletmeden almış olduğu hizmeti değerlendirmesi olarak tanımlanmaktadır ve gerçekleşen hizmet kalitesi, tüketicilerin kendilerine sunulan hizmetin kalitesine yönelik beklentileri ile aldıkları hizmetin kalitesine yönelik algıları arasındaki farkla açıklanmaktadır (Bknz. Kırcova, Köse ve Özer, 2020, s. 81-82; Martinez ve Martinez, 2010, s. 30; Parasuraman, Zeithaml ve Berry, 1985, s. 42-47)

Hizmet kalitesinin ölçümü konusunda araştırmacıların en sık kullandığı ölçek SERVQUAL ölçeğidir (Parasuraman, Zeithaml and Berry, 1988). Bu ölçekte hizmet kalitesi “Fiziksel Varlıklar, Güvenilirlik, Heveslilik, Güven, Empati” şeklinde beş boyutta 22 ifadeyle incelenmektedir. 1990'l1 yillardan itibaren farkl1 hizmet sektörlerinde kaliteyi ölçmeye yönelik SERVQUAL ölçeğinin revize versiyonları ya da yeni ölçüm modelleri tasarlanmaya başlanmıştır (Aydoğdu ve diğerleri, 2019, s. 160; Tuncer, 2017, s. 323; Hansen, 2014). Örneğin, GRSERV (Chen, Cheng ve Hsu, 2013), HOLSERV (Mei, Dean ve White, 1999), SERVPERF (Cronin ve Taylor, 1992), LODGSERV (Knutson, Stevens, Patton ve Yokohama, 1990) ve DINESERV (Stevens, Knutson ve Patton, 1995).

Söz konusu ölçeklerin önemli bir kısmının SERVQUAL ölçeğinden hareketle hazırlandıkları görülmektedir. Bu ölçeklerden DINESERV ölçeği de SERVQUAL ve LODGESERV baz alınarak, ifadelerin uyarlanmasıyla -ve çoğaltılmasıyla- yine beş boyutlu olarak tasarlanmıştır (Tuncer, 2017, s. 325-326; Hansen, 2014, s. 120; Stevens ve diğerleri, 1995). Kısaca DINESERV, “yiyecek içecek işletmelerinde sunulan hizmetin kalitesini ölçmeye yönelik geliştirilen bir kalite ölçüm yöntemi" olarak tanımlanmaktadır (K1lıç ve Kurnaz, 2019, s. 92).

Literatürde, ilk olarak fastfood ve restoranlarda yapılan bir araştırmada kullanılan ve daha sonra günlük ya da lüks restoran, kafe vb. her türlü yiyecek-içecek 
işletmesinde yürütülen araştırmalarda tercih edilmeye başlanan DINESERV ölçeğinin, müşteri bakış açısılyla bir yiyecek-içecek işletmesinde kalitenin ne düzeyde gerçekleştiğini tespit etmede kullanılan kolay ve güvenilir bir araç olduğu ifade edilmektedir (Kılıçhan ve Ülker, 2015, s. 887). Bu kolaylı̆̆1 ve güvenilirliği nedeniyle ölçek, araştırmacılar tarafından yeme-içme sektöründe hizmet kalitesini ölçmek üzere güncel araştırmalarda halen sıklıkla kullanılmaktadır. ${ }^{4}$ Örneğin, Chun ve Nyam-Ochir (2020) müşterilerin memnuniyet düzeylerinin aynı restoran zincirine tekrar gelme ve tavsiye davranışları üzerindeki etkilerini inceledikleri araştırmalarında; Adeinat (2019) aynı franchising markasıyla çalışan üç restoranın müşterilerinin hizmet kalite algılarını incelerken; Kim ve Choi (2019) istediğin kadar ye (all-you-can-eat) restoranlarda yöneticilerin hizmet standartları ile müşterin kalite algıları arasındaki farklılıkları ortaya koymak üzere yaptıkları çalışmalarında; Çiğdemli ve İştin (2018) restoranlarda müşterilerin hizmet kalite algılarını ölçmek üzere yaptıkları araştırmada DINESERV ölçeğini kullanmışlardır.

DINESERV ölçeğinde yer alan boyutlar çerçevesinde yiyecek-içecek işletmelerinde hizmet kalitesinin unsurları şu şekilde ifade edilebilir (Stevens ve diğerleri, 1995):

Fiziksel Unsurlar (Tangibles): Yiyecek içecek işletmelerinin hizmetlerinin sunumunda kullanılan arac,-gereçler, personel (diş görünüşüu), hizmetin sunulduğu mekân vb. unsurlar. Güvenilirlik (Reliability): Ortaya konulan hizmetlerde vaadin (örn. siparişlerin) güvenilir ve doğru bir şekilde yerine getirilebilmesi yeteneği. Heveslilik (Responsiveness): Hizmetin sunulduğu müşterilere yardımcı olma ve hizmeti hızlı/dakik bir şekilde yerine getirme istekliliği. Güven (Assurance): Hizmet sunanların/çalışanların sunulan hizmet hakkında (örn. menüler, yemeklerin yapılış şekli, kullanılan malzemeler vb. hususlarda) bilgi sahibi olmaları, müşterilere karşı nezaketleri ve onlarda güven yaratma kabiliyetleri. Empati (Emphaty): İşletmenin hizmetlerinin merkezine müşteriyi alması, müşterilerine özen göstermesi ve onlarla kişisel olarak ilgilenmesi.

\footnotetext{
${ }^{4}$ Yiyecek içecek işletmeleri özelinde yürütülen çalışmalarda, DINESERV ölçeğinde yer almayan ancak bu alanda incelenmesinin önemli olduğu düşünülen yemek kalitesi, fiyat-değer, menü çeşitliliğii, porsiyon büyüklüğü, evinde gibi hissetme vb. bazı spesifik konularla da araştırmacılar ilgilenmektedir (Bkz. Bekar ve Kılıç, 2015, s. 4).
} 
Bahsedilen unsurlar kalite konusunda iç-içe geçmiş halkalar olarak görülmelidir ve Hansen'e göre (2014, s. 117) zincirin bir halkası kırıldığında müşteri deneyimi bundan olumsuz etkilenebilmektedir. Söz konusu deneyimler, memnuniyet veya memnuniyetsizlik sonuçlarıyla birlikte müşterilerin tekrar ziyaret niyetlerini etkilemektedir. Dolayısıyla literatürde, yukarıda ifade edilen boyutlarla şekillenmekte olan hizmet kalitesine yönelik algıların müşteri memnuiyetini ve sadakatini etkilediği ifade edilmektedir. Bu kavramlar pazarlamanın temel değişkenlerinden olup (Kırcova ve diğerleri, 2020, s. 80) müşteri memnuniyeti kavramı, talep ve isteklerinin uygun bir şekilde yerine getirilmesi sonucu müşterinin, ürüne/hizmete ilişkin kalite algısının beklentilerine eşit veya beklentilerinin üzerinde gerçekleşmesiyle birlikte yaşayacağ1 mutluluk veya haz durumunu ifade eder (Kurnuç, Kurucuk ve Küçük, 2015, s. 24). Satın alınan ürün veya hizmete ulaşmak için ödenen -parasal ve parasal olmayanbedeller ile karşılığında elde edilen yararlar arasında negatif bir fark varsa müşteri memnuniyeti oluşmamakta, pozitifse memnuniyet gerçekleşmektedir. Elde edilen fayda ise elbette kaliteyle ilişkilidir. Kalite doğrultusunda memnuniyet oluştukça ve tekrarlanan alımlarda bu mekanizma gerçekleşmeye devam ettikçe zamanla da sadakat oluşmaktadır (Uyar, 2019, s. 46). Müşteri sadakati ise içerisinde davranışsal, duygusal, tutumsal vb. birçok yapıyı barındıran bir kavramdır (Küçükergin ve Uygur, 2013; Kumar ve Shah, 2004; Chaudhuri ve Holbrook, 2001) ve kısaca müşterilerin ilgili ürünü/hizmeti aynı yerden satın almaya devam etme davranışı, işletmenin devamlı müşterisi olma adına bireyde oluşmuş -bağl1lık yönlü- duyguyu ifade eder.

Hizmet kalitesi ile ilgili ulusal ve uluslararası literatüre bakıldığında yeme-içme sektöründe müşteri memnuniyetinin de müşteri sadakatinin de hizmet kalitesiyle -ve kalite alt boyutlarıyla- yakından ilgili olduğu görülmektedir (Bkz: Yangınlar ve Tuna, 2020; Bilgin, 2017; Chen, 2016; Aksu ve diğerleri, 2016; İlhan ve Kılıçhan, 2016; Diab, Mohammed, Mansour ve Saad, 2016; Bekar ve Kılıç, 2015; Haghigi, Dorosti, Rahnama ve Hoseinpour, 2012; Barber, Goodman ve Goh, 2011; Hyun, 2010; Bulgan, 2010; Ha ve Jang, 2010; Kim ve diğerleri, 2009; Andaleeb ve Conway, 2006). 


\section{ARAŞTIRMA YÖNTEMI}

\subsection{Araştırma Modeli ve Hipotezler}

Çalışmanın amacı yeme içme sektöründe faaliyette bulunan bir ulusal kahve zinciri şubesi örneğinde algılanan hizmet kalitesinin müşteri memnuniyeti ve sadakati üzerine etkisini ve ayrıca müşteri memnuniyetinin de sadakati açıklama durumunu incelemektir. Aksu ve diğerlerinin de $(2016$, s. 2) belirttiği gibi literatürdeki araştırma bulgularının bir kısmı hizmet kalitesinin müşteri memnuniyeti üzerindeki etkisini; bir kısmı ise müşteri memnuniyeti ve sadakati üzerinde etkisini göstermektedir. Ayrıca literatürde müşteri memnuniyetinin müşteri sadakatini açılayan değişkenlerden biri olduğu da ifade edilmektedir. Literatürdeki araştırmalarda yaklaşım olarak hizmet kalitesi algısının bir bütün olarak da, alt boyutları itibariyle de bahsedilen değişkenlerle incelendiği görülmektedir (Örn. Bekar ve Kılıç, 2015). Bu çalışma belirli bir işletmenin müşterileriyle yapıldığından, işletmeye sunulacak bilgi açısından alt boyutların memnuniyete ve sadakata etkilerini inceleme zorunluluğu da pratik anlamda doğmaktadır. Dolayısıyla Şekil 1'de görüldüğü üzere, araştırmada incelenecek olan modeller hem hizmet kalitesine yönelik toplam algının müşteri memnuniyeti ve sadakatine etkisi, hem kalitenin alt boyutlarının bu yapılara etkisi, hem de memnuniyetin sadakate etkisi çerçevesindedir. 

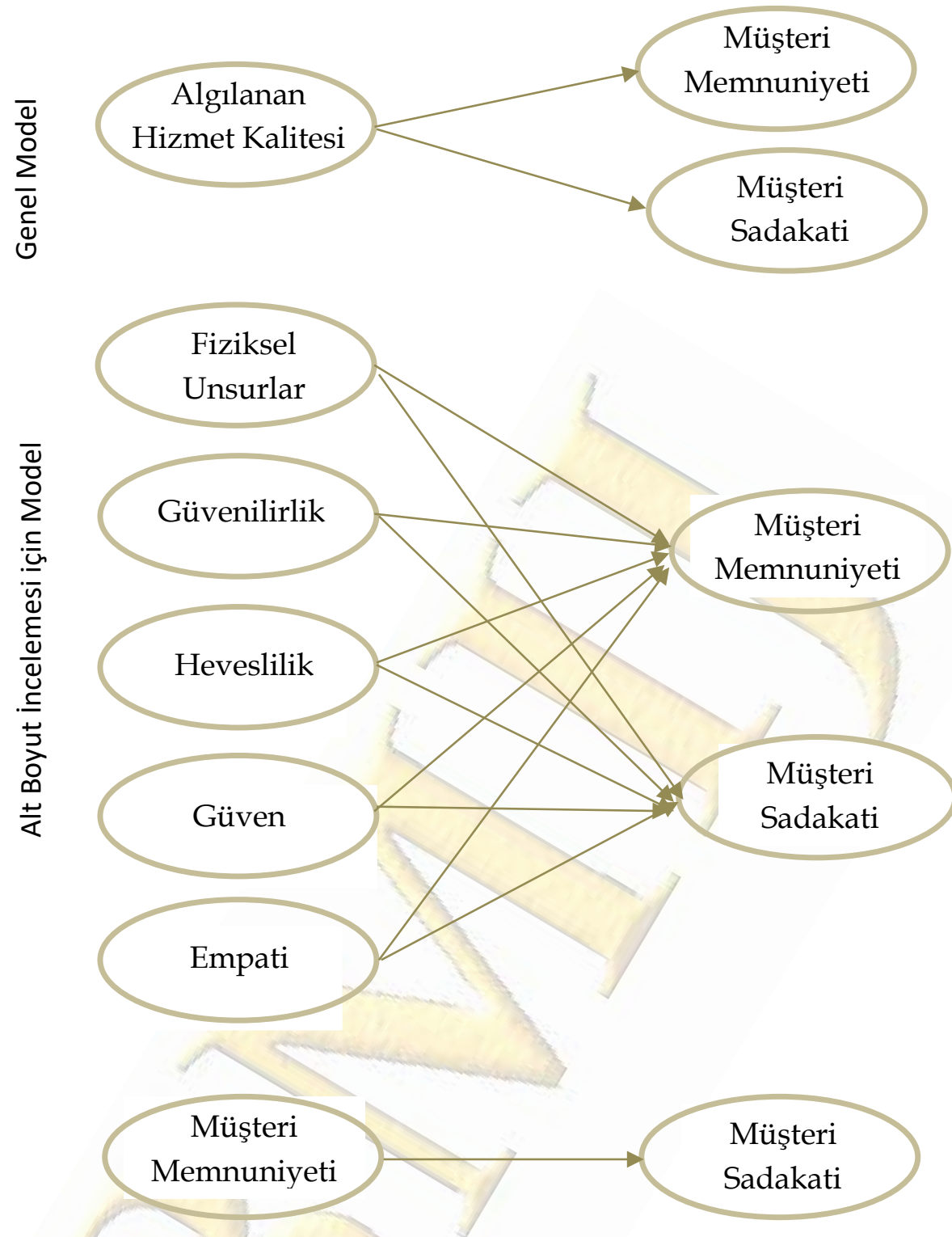

Şekil 1. Araştırmada İncelenen Modeller

Araştırmanın hipotezleri şu şekildedir:

$\boldsymbol{H}_{1}$ : Hizmet kalitesi, müşteri memnuniyetini pozitif yönde anlaml etkiler.

$H_{1 a}$ : Fiziksel unsurlar boyutu, müşteri memnuniyetini pozitif yönde anlaml etkiler.

H1b: Güvenilirlik boyutu, müşteri memnuniyetini pozitif yönde anlamlı etkiler.

$H_{1 c:}$ Heveslilik, müşteri memnuniyetini pozitif yönde anlamlı etkiler.

$H_{1 d:}$ Güven boyutu, müşteri memnuniyetini pozitif yönde anlamlı etkiler.

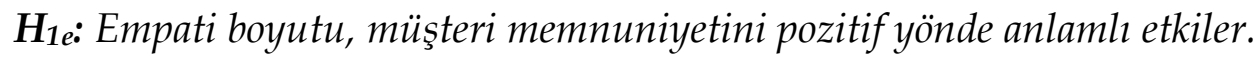

$H_{2}$ : Hizmet kalitesi, müşteri sadakatini pozitif yönde anlamlı etkiler. 
$\mathrm{H}_{2 a}$ : Fiziksel unsurlar boyutu, müşteri sadakatini pozitif yönde anlamlı etkiler.

$H_{2 b}$ : Güvenilirlik boyutu, müşteri sadakatini pozitif yönde anlamlı etkiler.

$\boldsymbol{H}_{2 c}$ : Heveslilik, müşteri sadakatini pozitif yönde anlamlı etkiler.

$\boldsymbol{H}_{2 d}$ : Güven boyutu, müşteri sadakatini pozitif yönde anlamlı etkiler.

$\mathbf{H}_{2 e}$ : Empati boyutu, müşteri sadakatini pozitif yönde anlaml etkiler.

$\boldsymbol{H}_{3}$ : Müşteri memnuniyeti, müşteri sadakatini pozitif yönde anlamlı etkiler.

Çalışmada ayrıca, demografik değişkenler itibariyle müşterilerin hizmet kalitesine dair algılarının, memnuniyetlerinin ve işletmeye karşı sadakat düzeylerinin gruplar arasında anlamlı olarak farklılaşıp farklılaşmadığı da incelenmektedir. İlgili hipotezler (birleştirilmiş olarak) aşağıda yer almaktadır. ${ }^{5}$

$\boldsymbol{H}_{4}$ : Katılımollarn hizmet kalitesine dair algzlarn $\left(H_{4 a}\right)$, memnuniyetleri $\left(H_{4 b}\right)$ ve sadakat düzeyleri $\left(H_{4 c}\right)$ cinsiyete göre gruplar arasında anlamlı olarak farklılaşmaktadır.

H5: Katılımcllarn hizmet kalitesine dair algılarn $\left(H_{5 a}\right)$, memnuniyetleri $\left(H_{5 b}\right)$ ve sadakat düzeyleri $\left(H_{5 c}\right)$ medeni duruma göre gruplar arasında anlamlı olarak farklılaşmaktadır.

H6: Katılımcilarn hizmet kalitesine dair algilarn $\left(H_{6 a}\right)$, memnuniyetleri $\left(H_{6 b}\right)$ ve sadakat düzeyleri $\left(H_{6 c}\right)$ eğitim düzeylerine göre gruplar arasında anlamlı olarak farklılaşmaktadır.

H7: Katılımcllarn hizmet kalitesine dair algılarn $\left(H_{7 a}\right)$, memnuniyetleri $\left(H_{7 b}\right)$ ve sadakat düzeyleri $\left(H_{7 c}\right)$ çalışma durumlarnna göre gruplar arasında anlamlı olarak farklılaşmaktadır.

H8: Katılımcularn hizmet kalitesine dair algılarn $\left(H_{8 a}\right)$, memnuniyetleri $\left(H_{8 b}\right)$ ve sadakat düzeyleri $\left(\mathrm{H}_{8 c}\right)$ gelire göre gruplar arasında anlamlı olarak farklılaşmaktadır.

Çalışmada son olarak katılımcıların hizmet kalitesi algılarının, memnuniyetlerinin ve sadakatlerinin, işletmeyi deneyimleme düzeylerine ve işletmeye geliş amaçlarına göre farklılaşıp farklılaşmadı̆̆ı da incelenmektedir. İlgili hipotezler şu şekildedir.

\footnotetext{
${ }^{5}$ Hizmet kalitesinin alt boyutları için tek tek hipotez kurgulanmamış olsa da analizlerde bu düzeyde de inceleme yapılmış, ilgili kısımda bu bulgulara yer verilmiştir.
} 
H9: Katılımcilarm hizmet kalitesine dair algilarn $\left(H_{9 a}\right)$, memnuniyetleri $\left(H_{9 b}\right)$ ve sadakat düzeyleri $\left(H_{9 c}\right)$ işletmeyi deneyimleme düzeylerine göre gruplar arasında anlaml olarak farklılaşmaktadır.

$H_{10}$ : Katılımcilarn hizmet kalitesine dair algzlarn $\left(H_{10 a}\right)$, memnuniyetleri $\left(H_{10 b}\right)$ ve sadakat düzeyleri $\left(\mathrm{H}_{10 c}\right)$ işletmeye geliş amaçlarına göre gruplar arasında anlamlı olarak farklılaşmaktadır.

\section{2. Örneklem, Araç ve Yöntem}

Çalışmanın anakütlesini yeme-içme sektöründe faaliyette bulunan zincir bir işletmenin Kahramanmaraş şubesine gelen müşteriler oluşturmaktadır. İşletmeden araştırma öncesinde gerekli izinler alınmıştır. Nicel araştırma yöntemlerinden anket tekniğinin kullanıldığı araştırma, kolayda örnekleme yoluyla, 14-20 Aralık 2019 tarihleri arasında, mekâna farklı saatlerde gelen müşterilerin profilleri ve aldıkları hizmetler farklılaşabileceğinden farklı deneyimleri olan müşterilerin araştırmada temsil edilebilmeleri adına 10:00-24:00 saatleri arasında -10:00-13:00, 14:00-18:00 ve 19:00-24:00 olmak üzere üç zaman diliminde- yürütülmüştür. ${ }^{6} 551$ kişiye masalarında- anket uygulanmış, geçersiz kabul edilen 27 form elendikten sonra 524 anketten elde edilen veri analizlere alınmıştır. [Not: Veriler 01.01.2020 tarihinden önce toplandığ1 için Etik Kurul Raporu gerekmemektedir.] Bulgular kısmında N örneklem büyüklüğünün ve alt gruplarda n gözlem sayısının değişkenlik arzettiği görülecektir. Bu durum hem ilgili kısmı cevaplandırmamayı tercih edenler, hem de ölçeklerde 7'li skala haricinde "tecrübe etmedim, fikrim yok, bu sebeple değerlendiremem" seçeneğinin sunulması nedeniyle ${ }^{7}$ bu şıkkı işaretleyenlerin varlı̆̆ından kaynaklanmaktadır.

Çalışmada kullanılan anket formu üç bölümden oluşmuştur. Birinci bölümde katılımcıların demografik bilgilerini edinmeye yönelik kapalı ve açık uçlu sorular bulunmaktadır. Bu kısımda katılımcıların işletmeyi deneyimleme durumları da "ilk

\footnotetext{
${ }^{6}$ Yazarlar, araştırma sürecine katkıda bulunan İstar Danışmanlık İstatistik \& Araştırma'nın sahibi Murat Bayazıt'a, K.S.Ü. S.B.E. lisansüstü öğrencileri Mustafa Aslan ve Berna Karadana'ya ve araştırmanın kendi işletmelerinde gerçekleşmesine izin veren işletme sahibi ve yöneticilerine teşekkür eder.

${ }^{7}$ Bu seçeneğin ilave edilmesi, örneğin tuvalet vb. alanları kullanmayan katılımcıların, ya da "bir yanlışlık olduğunda durum hızlı bir şekilde düzeltilir" örneğindeki gibi durumları henüz tecrübe etmemiş/böyle bir duruma şahit olmamış olan katılımcılar nedeniyledir. Böylelikle katılımcılar bir büyüklük ifade eden ölçek seçeneklerini işaretlemek zorunda kalmamaktadır.
} 
kez geliş, daha önce de gelmiş olmak ve müdavimi olmak" çerçevesinde sorulmuştur. Katılımcılara ayrıca bu işletmeye gelişlerindeki birincil amacın ne olduğuna dair soru (yeme-içmeyle ilgili nedenler, sosyalleşme içerikli nedenler gibi) yöneltilmiştir.

Anketin ikinci bölümünde Stevens ve diğerleri (1995) tarafından yeme-içme sektöründe hizmet kalitesini ölçmek üzere geliştirilen DINESERV ölçeği yer almaktadır. Bu ölçek 5 boyuttan ve 29 önermeden oluşmaktadır. Ölçekte iki ayrı değerlendirme unsuru barındıran (Örn. "park alanı ve binanın dış yapısı", "çalışanlar sempatiktir ve yanlışlı/sorun olduğunda bunun düzeltilmesi/telafi edilmesiyle ilgili güven verir" gibi) ifadeler ikiye bölünmüştür. Nihai ölçekte "Yeme-içme alanı göze hitap eder.", "Özel bir talep olduğunda, onu karşılayabilmek için ekstra çaba sarf edilir.", "Herhangi bir yanlış/hata olduğunda bu durum hızlı bir şekilde düzeltilir.", "Menüde yer alan yemekler ve içecekler ile, bunların hazırlanma yöntemi ve içindeki malzemeler hakkında bilgi verebilen personeli vardır.", "[İşletmenin Adı] politikaları ve prosedürlerine bağhı kalmayıp müşterilerin bireysel istek ve ihtiyaçlarına duyarl olan çalışanlara sahiptir.", "[İsletmenin Adı]..... müşterinin yararını/çıkarını gönülden benimser." örneklerindeki gibi hazırlanmış toplam 32 ifade bulunmaktadır. Ölçeğin güvenilirliği test edilmiştir (Cronbach's alpha: 0,98). Söz konusu ölçeğin alt boyutları literatürde yerleşik boyutlar olduğundan, ölçeğin bilimsel yapısının bozulmaması adına faktör analizi yapılmamış, bunun yerine alt boyutları kendi içlerinde tek bir yapı olarak alıp her biri için tekrar güvenilirlik analizi yapılmıştır (Fiziksel unsurlar için Cronbach's alpha: 0,90; Güvenilirlik için Cronbach's alpha: 0,89; Heveslilik için Cronbach's alpha: 0,87; Güven için Cronbach's alpha: 0,94; Empati için Cronbach's alpha: 0,94). Anketin üçüncü bölümünde müşteri memnuniyeti ve sadakati ölçekleri yer almaktadır. Memnuniyet ölçeği yazarlar tarafından hazırlanmış olup, yedi maddeden oluşmaktadır (Cronbach's alpha: 0,90). İadeler "hizmetlerden, yemek çeşitlerinden, içeceklerden, tatllardan, mekândan, çalışanlardan ve bir bütün olarak işletmeden" memnun olma şeklinde kat1liyorumkatılmıyorum düzeyleriyle 7'li aralıklı ölçekte sunulmuştur. Sadakat ölçeğinde ise dört madde yer almakta olup ("gelecekte tekrar gelme, çevreye tavsiye etme, işletmeyi diğerlerine tercih etme, fiyatlar artsa bile yine de bu mekâna gelmeye devam etme"), bu maddeler katılıyorum-katılmıyorum şeklindeki 7'li aralıklı ölçekte sunulmuştur (Cronbach's alpha: 0,78). Tüm ölçekler kabul edilebilir güvenilirliğe sahip olduğundan, analizlere 
geçilmiş; SPSS programı ile regresyon analizi, bağımsız örneklemler için $t$-testi ve ANOVA ile Tukey-Kramer ve Scheffe Post-Hoc testleri yapılmıştır.

\section{BULGULAR}

\subsection{Katılımcıları Betimleyici İstatistikler}

Katılımcılara ilişkin demografik bilgiler Tablo 1'de sunulmuştur. Katılımcıların çoğunluğu erkek $(\% 53,8)$, 25 yaş ve altında $(\% 68,9)$ ve bekardır $(\% 86,9)$. Cevaplayıcıların yarıya yakını öğrenci olup, dörtte biri -tam zamanlı ya da yarı zamanl1- çalışandır. Cevaplayıcıların çoğunluğu 2500 ve altında bir gelire (öğrenciler için harçlık, burs vb. toplamı) sahip olduğunu belirtirken, 5000 TL ve üzeri gelire sahip olanlar katılımcıların yaklaşık \%20'sidir. Lise ve altında bir eğitim seviyesine sahip olanların cevaplayıcıların \%33,2'sini oluşturduğu, çoğunluğun lisans ve lisansüstü düzeyde eğitime sahip oldukları -bu seviyelerde halen öğrenci olanlar dahilgörülmektedir.

Tablo 1. Kat1lımcıların Demografik Bilgileri

\begin{tabular}{|c|c|c|c|c|c|}
\hline Cinsiyet & $\mathrm{n}$ & $\%$ & Medeni Durum & $\mathrm{n}$ & $\%$ \\
\hline Kadın & 242 & 46,2 & Evli & 67 & 13,1 \\
\hline Erkek & 282 & 53,8 & Bekar & 446 & 86,9 \\
\hline Toplam & 524 & 100,0 & Toplam & 513 & 100,0 \\
\hline Yaş & $\mathrm{n}$ & $\%$ & Gelir Durumu & $\mathrm{n}$ & $\%$ \\
\hline $18-21$ & 175 & 33,7 & 2500 TL ve alt1 & 251 & 57,6 \\
\hline $22-25$ & 183 & 35,2 & $2501-5000 \mathrm{TL}$ & 100 & 22,9 \\
\hline $26-29$ & 86 & 16,5 & 5001 TL ve üzeri & 85 & 19,5 \\
\hline 30 üstü & 76 & 14,6 & Toplam & 436 & 100,0 \\
\hline Toplam & 520 & 100,0 & Eğitim Durumu & $\mathrm{n}$ & $\%$ \\
\hline Çalışma Durumu & $\mathrm{n}$ & $\%$ & İlköğretim & 45 & 8,6 \\
\hline Öğrenci & 255 & 48,9 & Lise & 128 & 24,6 \\
\hline Çalışan* & 139 & 26,6 & Önlisans & 64 & 12,3 \\
\hline İşyeri Sahibi & 62 & 11,9 & Üniversite & 228 & 43,8 \\
\hline Çalışmiyor & 66 & 12,6 & Lisansüstü (YL-Dr) & 56 & 10,7 \\
\hline Toplam & 522 & 100,0 & Toplam & 522 & 100,0 \\
\hline
\end{tabular}

Tablo 2' de katılımcıların işletmeyi deneyimleme durumları sunulmaktadır. Söz konusu işletmeye ilk defa gelenlerin katılımcılar arasında küçük bir grup oluşturduğu $(\% 8,5)$, mekâna daha önce gelen ve mekânın müdavimi olan, kısaca deneyim seviyesi yüksek olan grupların örneklemde ağırlıkta olduğu görülmektedir. 
Tablo 2. Katılımcıların Deneyim Durumları ve İşletmeye Geliş Amaçları

\begin{tabular}{|c|c|c|}
\hline Deneyimleme Durumu & $n$ & $\%$ \\
\hline "Buraya ilk gelişim." & 44 & 8,5 \\
\hline "Buraya daha önce de gelmiştim." & 238 & 45,8 \\
\hline "Buranın müdavimiyim." & 238 & 45,8 \\
\hline Toplam & 520 & 100,0 \\
\hline Geliş Amacı & $n$ & $\%$ \\
\hline Arkadaşlarla birlikte vakit geçirmek & 162 & 30,98 \\
\hline Kahve içmek & 161 & 30,78 \\
\hline Menü (içecekler, yiyecekler, tatlıları) için & 89 & 17,01 \\
\hline Sükûnet, huzur bulmak, kafa dinlemek & 49 & 9,37 \\
\hline Yeni insanlarla tanışmak & 23 & 4,40 \\
\hline Aileyle birlikte vakit geçirmek & 20 & 3,82 \\
\hline Eğlenmek & 19 & 3,64 \\
\hline Toplam & 523 & 100 \\
\hline
\end{tabular}

Tablo 2'de katılımcıların işletmeye geliş amacına ilişkin bulgular da yer almaktadır. Bu soruda birincil amacı tespit etmek hedeflendiğinden, anket formunda tek yanıt hakkı tanımlanmıştır. Tabloya göre, en sık belirtilen üç amaç "arkadaşlarla vakit geçirmek, kahve içmek ve menüyü beğeniyor olmak"tır ve "eğlenmek, aileyle birlikte vakit geçirmek ve yeni insanlarla tanışmak" en düşük frekansa sahip üç seçenektir.

\subsection{Algılanan Hizmet Kalitesinin ve Alt Boyutlarının Müşteri Memnuniyeti} ve Sadakatine Etkisi

Ölçek ortalamaları algılanan hizmet kalitesi için $\bar{X}: 5,53$ (ss: 1,23), memnuniyet için $\bar{X}: 5,63$ (ss: 1,26) ve sadakat için $\bar{X}: 5,40$ (ss: 1,40) şeklinde gerçekleşmiştir. Hizmet kalitesinin alt boyutlarında ise ortalamaların -en olumlu değerlendirilen boyuttan başlamak suretiyle sırayla- güvenilirlik için $\bar{X}: 5,73$ (ss: 1,26), heveslilik için $\bar{X}: 5,53$ (ss: 1,49), güven için $\bar{X}: 5,52$ (ss: 1,37) fiziksel unsurlar için $\bar{X}: 5,45$ (ss: 1,16$)$, empati için $\bar{X}: 5,44$ (ss: 1,49) olduğu görülmektedir.

Tablo 3'te algılanan hizmet kalitesinin müşteri memnuniyetine etkisinin incelendiği regresyon analizinin bulguları yer almaktadır. Tabloya göre algılanan hizmet kalitesi $(\beta=0,781)$ müşteri memnuniyetini pozitif yönde ve anlamlı olarak etkilemektedir. Dolayısıyla $\mathrm{H}_{1}$ hipotezi kabul edilmiştir. Burada $\mathrm{R}^{2}$ açıklanan varyans 0,61 düzeyindedir. 
Tablo. 3. Alg1lanan Hizmet Kalitesinin Müşteri Memnuniyetine Etkisine İlişkin Regresyon Analizi Sonuçları

\begin{tabular}{|c|c|c|c|c|c|c|c|c|}
\hline & \multicolumn{2}{|c|}{$\begin{array}{l}\text { Standardize } \\
\text { Edilmemiş }\end{array}$} & $\begin{array}{l}\text { Standardize } \\
\text { edilmiş }\end{array}$ & $\mathrm{T}$ & $\mathrm{P}$ & $\mathrm{F}$ & R2 & $\Delta \mathrm{R} 2$ \\
\hline $\begin{array}{l}\text { Bağımsız } \\
\text { değişkenler }\end{array}$ & B & $\begin{array}{c}\text { Standart } \\
\text { hata }\end{array}$ & Beta $(\beta)$ & & & & & \\
\hline Sabit & 1,228 & 159 & & 7,744 & ,000 & $811,68^{* * *}$ & 0,61 & 0,61 \\
\hline Hizmet kalitesi & 796 & ,028 & 781 & 28,490 & ,000 & & & \\
\hline
\end{tabular}

Tablo 4'te hizmet kalitesinin alt boyutlarındaki algıların müşteri memnuniyetine etkisinin incelendiği regresyon analizinin bulguları yer almaktadır. Öncelikle modelde çoklu eş doğrusallık (bağıntı) problemi olup olmadığını gösteren tolerans değeri (TD) ve varyans artış faktörü (VIF) değerleri incelendiğinde; VIF değerlerinin tamamının 10' dan küçük olduğu ve tolerans değerlerinin de tamamının 0,10'dan büyük olduğu görülmektedir. Değerler kabul edilebilir aralıkta olduğundan (Bknz. Çoban ve Demirhan, 2019, s. 91; Büyükuysal ve Öz, 2016, s. 111; Koç, Kaya, Özbek ve Akkılıç, 2014, s. 16-19), regresyon bulguları incelenebilir. Tablo 4'e göre fiziksel unsurlara ilişkin algılar $(\beta=0,343)$ ile güven $(\beta=0,140)$ ve empati $(\beta=0,235)$ boyutlarındaki algılar, müşteri memnuniyetini pozitif yönde ve anlamlı olarak etkilemektedir. Burada etki büyükleri açısından sıralama, fiziksel unsurlar, empati ve güven şeklinde gerçekleşmiştir. Tablo 4'e göre, $\mathrm{H}_{1 \mathrm{a}}, \mathrm{H}_{1 \mathrm{~d}}$ ve $\mathrm{H}_{1 \mathrm{e}}$ hipotezleri kabul, $\mathrm{H}_{1 \mathrm{~b}}$ ve $\mathrm{H}_{1 \mathrm{c}}$ hipotezleri reddedilmiştir.

Tablo 4. Hizmet Kalitesinin Alt Boyutlarının Müşteri Memnuniyetine Etkisine İlişkin Regresyon Analizi Sonuçları

\begin{tabular}{|c|c|c|c|c|c|c|}
\hline & $\begin{array}{l}\text { Standardize } \\
\text { Edilmemiş }\end{array}$ & $\begin{array}{l}\text { Standardize } \\
\text { edilmiş }\end{array}$ & & \multicolumn{3}{|c|}{$\begin{array}{l}\text { İç İlişki } \\
\text { İstatistikleri }\end{array}$} \\
\hline Bağımsız değ. & B S. Hata & Beta $(\beta)$ & $\mathrm{T}$ & $\mathrm{P}$ & TD & VIF \\
\hline Sabit & 1,050 & & 6,158 & ,000 & & \\
\hline Fiziksel Unsurlar & 053 & 343 & 7,062 & ,000 & ,30 & 3,2 \\
\hline Güvenilirlik & , 081 & ,081 & 1,506 & 133 & ,25 & 3,9 \\
\hline Heveslilik & ,044 & ,066 & 1,252 & 211 & ,26 & 3,7 \\
\hline Güven & 061 & 140 & 2,111 & ,035 & 16 & 6,0 \\
\hline Empati & 047 & ,235 & 4,280 & ,000 & 24 & 4,1 \\
\hline
\end{tabular}

F: 172,821***, R2: 0,63, $\Delta \mathrm{R}^{2}: 0,62$, Bağımlı değişken: Müşteri Memnuniyeti, $\left({ }^{*} \mathrm{p}<0,05{ }^{* *} \mathrm{p}<0,01{ }^{* * *} \mathrm{p}<0,001\right)$

Tablo 5'te algılanan hizmet kalitesinin müşteri sadakatine etkisinin incelendiği regresyon analizinin bulguları yer almaktadır. Tabloya göre algılanan hizmet kalitesi $(\beta=0,654)$, müşteri sadakatini pozitif yönde ve anlamlı olarak etkilemektedir. 
Dolayısıyla $\mathrm{H}_{2}$ hipotezi kabul edilmiştir. Burada $\mathrm{R}^{2}$ açılanan varyans 0,43 düzeyindedir.

Tablo 5. Hizmet Kalitesinin Müşteri Sadakatine Etkisine İlişkin Regresyon Analizi Sonuçları

\begin{tabular}{|c|c|c|c|c|c|c|c|c|}
\hline & \multicolumn{2}{|c|}{$\begin{array}{l}\text { Standardize } \\
\text { Edilmemiş }\end{array}$} & $\begin{array}{c}\text { Standardize } \\
\text { edilmiş }\end{array}$ & $\mathrm{T}$ & $\mathrm{P}$ & $\mathrm{F}$ & $\mathrm{R} 2$ & $\Delta \mathrm{R} 2$ \\
\hline $\begin{array}{l}\text { Bağımsız } \\
\text { değişkenler }\end{array}$ & B & $\begin{array}{c}\text { Standart } \\
\text { hata }\end{array}$ & Beta $(\beta)$ & & & & & \\
\hline Sabit & 1,308 & 213 & & 6,127 & ,000 & $* * * 388,287$ & 0,43 & 0,43 \\
\hline Hizmet kalitesi & ,741 & ,038 & ,654 & 19,705 & ,000 & & & \\
\hline
\end{tabular}

Tablo 6' da hizmet kalitesinin alt boyutlarındaki algıların müşteri sadakatine etkisinin incelendiği regresyon analizinin bulguları yer almaktadır. Öncelikle tablodaki VIF ve tolerans değerleri kontrol edilmiş; VIF değerlerinin tamamının 10'dan küçük olması ve tolerans değerlerinin tamamının 0,10'dan büyük olması nedeniyle [Tablo 6'daki bağımsız değişkenler Tablo 4'tekilerle aynı olduğundan değerler de aynıdır] regresyon bulguları değerlendirmeye alınmıştır. Tabloya göre fiziksel unsurlara ilişkin algılar $(\beta=0,316)$ ile güvenilirlik $(\beta=0,147)$ ve empati $(\beta=0,245)$ boyutlarındaki algılar, müşteri sadakatini pozitif yönde ve anlamlı olarak etkilemektedir. Bu modelde etki büyüklükleri açısından sıralama fiziksel unsurlar, empati ve güvenilirlik şeklinde gerçekleşmiştir. Tablo 6'ya göre $\mathrm{H}_{2 a}, \mathrm{H}_{2 b}$ ve $\mathrm{H}_{2 \mathrm{e}}$ hipotezleri kabul, $\mathrm{H}_{2 \mathrm{c}}$ ve $\mathrm{H}_{2 \mathrm{~d}}$ hipotezleri reddedilmiştir.

Tablo 6. Hizmet Kalitesinin Alt Boyutlarının Müşteri Sadakatine Etkisine İlişkin Regresyon Analizi Sonuçları

\begin{tabular}{|c|c|c|c|c|c|c|c|}
\hline & $\begin{array}{l}\text { Star } \\
\text { Edi }\end{array}$ & $\begin{array}{l}\text { ardize } \\
\text { nemiş }\end{array}$ & $\begin{array}{l}\text { Standardize } \\
\text { edilmiş }\end{array}$ & & & \multicolumn{2}{|c|}{$\begin{array}{l}\text { İç İlişki } \\
\text { İstatistikleri }\end{array}$} \\
\hline Bağımsız değ. & B & S. Hata & Beta $(\beta)$ & $\mathrm{T}$ & $\mathrm{P}$ & TD & VIF \\
\hline Sabit & 1,021 & ,230 & & 4,439 & , 000 & & \\
\hline Fiziksel Unsurlar &, 381 & 071 & 316 & 5,364 & ,000 & ,30 & 3,2 \\
\hline Güvenilirlik & 163 & ,072 & 147 & 2,260 & ,024 & 25 & 3,9 \\
\hline Heveslilik &,- 029 & ,060 &,- 031 &,- 491 & 623 & 26 & 3,7 \\
\hline Güven & ,052 & ,082 & ,051 & 636 &, 525 & ,16 & 6,0 \\
\hline Empati & 230 & ,063 & 245 & 3,667 &, 000 & 24 & 4,1 \\
\hline
\end{tabular}

\subsection{Müşteri Memnuniyetinin Müş̧teri Sadakatine Etkisi}

Tablo 7 'de müşteri memnuniyetinin müşteri sadakatine etkisinin incelendiği regresyon analizinin bulguları yer almaktadır. Tabloya göre müşteri memnuniyeti $(\beta=0,758)$ müşteri sadakatini pozitif yönde ve anlamlı olarak etkilemektedir. Katsayı 
doğrultusunda müşteri memnuniyetindeki 1 birimlik artışın, sadakati 0,75 artırabileceği söylenebilir. Dolayısıyla $\mathrm{H}_{3}$ hipotezi kabul edilmiştir. Burada $\mathrm{R}^{2}$ açıklanan varyans 0,57 düzeyinde gerçekleşmiştir.

Tablo 7. Müşteri Memnuniyetinin Müşteri Sadakatine Etkisine İlişkin Regresyon Analizi Sonuçları

\begin{tabular}{|c|c|c|c|c|c|c|c|c|}
\hline \multirow[b]{2}{*}{$\begin{array}{l}\text { Bağımsız } \\
\text { değişkenler }\end{array}$} & \multicolumn{2}{|c|}{$\begin{array}{l}\text { Standardize } \\
\text { Edilmemiş }\end{array}$} & \multirow{2}{*}{$\begin{array}{c}\text { Standardize } \\
\text { edilmiş } \\
\text { Beta }(\beta)\end{array}$} & \multirow[t]{2}{*}{$\mathrm{T}$} & \multirow[t]{2}{*}{$\mathrm{P}$} & \multirow[t]{2}{*}{$\mathrm{F}$} & \multirow[t]{2}{*}{ R2 } & \multirow[t]{2}{*}{$\Delta \mathrm{R} 2$} \\
\hline & B & $\begin{array}{c}\text { Standart } \\
\text { hata }\end{array}$ & & & & & & \\
\hline Sabit & 650, & 183, & & & ,000 & $705,571^{\star * *}$ & ,575, &, 574 \\
\hline Memnuniyet & 844 & ,032 & ,758 & 26,56 &, 000 & & & \\
\hline
\end{tabular}

\section{4. $t$-testi ve ANOVA Sonuçları}

$\mathrm{Bu}$ bölümde demografik özellikleri itibariyle katılımcıların hizmet kalitesi algıları, memnuniyetleri ve sadakatleri incelenmiştir. İlk olarak Tablo 8' de cinsiyet itibariyle katılımcıların yanıtlarında farklılaşma olup olmadığına dair $t$-testi sonuçları yer almaktadır. Tabloya göre, kadınların genel olarak hizmet kalitesi algısı erkeklere kıyasla istatistiksel olarak anlamlı oranda yüksektir. Alt boyutlarda ise güvenilirlik, heveslilik ve empati açısından kadınların erkeklere kıyasla daha olumlu algıları olduğu görülmektedir. Cinsiyet itibariyle katılımciların memnuniyet ve sadakat yanıtlarında ise anlamlı bir farklılık bulunmamaktadır. Dolayısıyla $\mathrm{H}_{4 a}$ hipotezi kabul edilmiş, $\mathrm{H}_{4 \mathrm{~b}}$ ve $\mathrm{H}_{4 \mathrm{c}}$ hipotezleri ise reddedilmiştir.

Tablo 8. Cinsiyet İtibariyle $t$-Testi Sonuçları

\begin{tabular}{|c|c|c|c|c|c|c|}
\hline has & Cinsiyet & $\mathrm{n}$ & $\bar{X}$ & ss & $t$ & Sig. \\
\hline \multirow{2}{*}{$\begin{array}{l}\text { Algılanan } \\
\text { Hizmet Kalitesi }\end{array}$} & Kadın & 240 & 5,6711 & 1,22282 & \multirow[b]{2}{*}{2,346} & \multirow[b]{2}{*}{,019* } \\
\hline & Erkek & 280 & 5,4166 & 1,26487 & & \\
\hline \multirow{2}{*}{ Fiziksellik } & Kadın & 240 & 5,5521 & 1,13643 & \multirow{2}{*}{1,871} & \multirow{2}{*}{,062 } \\
\hline & Erkek & 280 & 5,3607 & 1,35381 & & \\
\hline \multirow{2}{*}{ Güvenilirlik } & Kadın & 240 & 5,8706 & 1,25926 & \multirow{2}{*}{2,292} & \multirow{2}{*}{, $022^{*}$} \\
\hline & Erkek & 280 & 5,6169 & 1,22107 & & \\
\hline \multirow{2}{*}{ Heveslilik } & Kadın & 240 & 5,6889 & 1,48791 & \multirow{2}{*}{2,258} & \multirow{2}{*}{, $024^{*}$} \\
\hline & Erkek & 280 & 5,3929 & 1,47765 & & \\
\hline \multirow{2}{*}{ Güven } & Kadın & 240 & 5,6339 & 1,37136 & \multirow{2}{*}{1,743} & \multirow{2}{*}{,082 } \\
\hline & Erkek & 280 & 5,4229 & 1,31003 & & \\
\hline \multirow{2}{*}{ Empati } & Kadın & 240 & 5,6099 & 1,47978 & \multirow{2}{*}{2,456} & \multirow{2}{*}{, $014^{*}$} \\
\hline & Erkek & 280 & 5,2896 & 1,42496 & & \\
\hline \multirow{2}{*}{ Memnuniyet } & Kadın & 241 & 5,6754 & 1,23621 & \multirow{2}{*}{ 689 } & \multirow{2}{*}{, 491} \\
\hline & Erkek & 282 & 5,5992 & 1,33823 & & \\
\hline \multirow{2}{*}{ Sadakat } & Kadın & 241 & 5,4423 & 1,37343 & \multirow[b]{2}{*}{, 594} & \multirow[b]{2}{*}{, 553} \\
\hline & Erkek & 282 & 5,3691 & 1,58912 & & \\
\hline
\end{tabular}


Tablo 9' da medeni durum itibariyle katılımcıların yanıtlarında farklılaşma olup olmadığına dair t-testi sonuçları yer almaktadır. Bu sonuçlara göre, katılımcıların evli ya da bekar olmasının hizmet kalitesi algılarını, memnuniyetlerini ve sadakatlerini etkilemediği görülmektedir. Dolayısıyla $\mathrm{H}_{5 a}, \mathrm{H}_{5 b}$ ve $\mathrm{H}_{5 c}$ hipotezleri reddedilmiştir. Ancak hizmet kalitesinin alt boyutu olan "empati" açısından, evli olan katılımcıların bekar olanlara kıyasla istatistiksel olarak anlamlı şekilde daha olumlu cevap verdikleri görülmüştür.

Tablo 9. Medeni Durum İtibariyle $t$-Testi Sonuçları

\begin{tabular}{|c|c|c|c|c|c|c|}
\hline & Medeni Durum & $\mathrm{n}$ & $\bar{X}$ & ss & $t$ & Sig. \\
\hline \multirow{2}{*}{ Alg1lanan Hizmet Kalitesi } & Bekar & 443 & 5,5064 & 1,22282 & \multirow{2}{*}{$-1,592$} & \multirow{2}{*}{,112 } \\
\hline & Evli & 67 & 5,7628 & 1,26487 & & \\
\hline \multirow{2}{*}{ Fiziksel } & Bekar & 443 & 5,4462 & 1,13643 & \multirow{2}{*}{,- 300} & \multirow{2}{*}{,764 } \\
\hline & Evli & 67 & 5,4921 & 1,35381 & & \\
\hline \multirow{2}{*}{ Güvenilirlik } & Bekar & 443 & 5,7032 & 1,25926 & \multirow{2}{*}{$-1,637$} & \multirow{2}{*}{ 102 } \\
\hline & Evli & 67 & 5,9724 & 1,22107 & & \\
\hline \multirow{2}{*}{ Heveslilik } & Bekar & 443 & 5,5004 & 1,48791 & \multirow{2}{*}{$-1,185$} & \multirow{2}{*}{,236 } \\
\hline & Evli & 67 & 5,7313 & 1,47765 & & \\
\hline \multirow{2}{*}{ Güven } & Bekar & 443 & 5,4953 & 1,37136 & \multirow{2}{*}{$-1,480$} & \multirow{2}{*}{,139 } \\
\hline & Evli & 67 & 5,7598 & 1,31003 & & \\
\hline \multirow{2}{*}{ Empati } & Bekar & 443 & 5,3870 & 1,47978 & \multirow{2}{*}{$-2,442$} & \multirow{2}{*}{, $015^{*}$} \\
\hline & Evli & 67 & 5,8585 & 1,42496 & & \\
\hline \multirow{2}{*}{ Memnuniyet } & Bekar & 446 & 5,6003 & 1,23621 & \multirow{2}{*}{$-1,841$} & \multirow{2}{*}{, 066} \\
\hline & Evli & 67 & 5,9018 & 1,33823 & & \\
\hline \multirow{2}{*}{ Sadakat } & Bekar & 446 & 5,3630 & 1,37343 & \multirow{2}{*}{$-1,455$} & \multirow{2}{*}{ 146 } \\
\hline & Evli & 67 & 5,6306 & 1,58912 & & \\
\hline
\end{tabular}

Tablo 10'da eğitim seviyesi itibariyle katılımcıların yanıtlarında farklılaşma olup olmadığına dair ANOVA sonuçları yer almaktadır. Bu sonuçlara göre, katılımcıların eğitim seviyeleri itibariyle hizmet kalitesi algıları, memnuniyetleri ve sadakatleri istatistiksel olarak anlamlı şekilde farklılaşmamaktadır. Dolayısıyla $\mathrm{H}_{6 a}$, $\mathrm{H}_{6 \mathrm{~b}}$ ve $\mathrm{H}_{6 \mathrm{c}}$ hipotezleri reddedilmiştir. Ancak algılanan hizmet kalitesinin "güven" boyutunda gruplar arasında anlamlı farklılık olduğu görülmüştür. Farklılığın hangi gruplar arasında olduğunu görmek için yapılan Tukey-Kramer Post-Hoc testi ${ }^{8}$ sonucuna göre, lise eğitim düzeyine sahip olan grupların (Ort.: 5,63), önlisans eğitimi

\footnotetext{
${ }^{8}$ Post-Hoc testlerden Scheffe, Bonferoni gibi testler (Tablo 13 hariç) ANOVA bulgularının aksine sonuç vererek, gruplar arasında anlamlı farklılık göstermemiştir. Bu durum tip II hatanın oluşmasına, yani gerçekte bulgu hipotezi destekliyorken, desteklemiyormuş görünmesine yol açmaktadır. Temel alınması gereken analiz Post-Hoc test değil, ANOVA olduğundan, tip II hata oluşmaması adına, çalışmada anlamlı fark yanıtı veren Tukey-Kramer testi bulguları paylaşılmıştır. Tukey testinde karşılaştırılan grup büyüklüklerinin eşit olması gerekirken, Tukey-Kramer'de bu zorunluluk bulunmamaktadır (Kramer, 1956) ve harmonik ortalama alınmak suretiyle gruplar karşılaştıılmaktadır. SPSS'te yer alan Tukey testinin, karşılaştırılan grup büyüklükleri eşit olmadığında otomatik olarak Tukey-Kramer testi olarak çalıştığını belirtmek gerekir. Bu durum IBM tarafından da açıklanmıştır (Bknz. IBM, ty). Öte yandan, Tukey-Kramer'de tip I hata oluşma ihtimalini de unutmamak gerekir. ANOVA analizinin farklılık yok dediği bir bulguya Tukey-Kramer testinin farklılık var demesiyle ortaya çıkabilen bir tip I hata bu çalışma için söz konusu olmadığından, araştırmacılar Tukey-Kramer testi bulgularını paylaşmayı tercih etmiştir. İstisna olarak Tablo 13'teki ANOVA sonuçlarıyla eksiksiz uyumlu sonuç verdiği için ilgili kısımda Scheffe testi bulguları paylaşılmıştır.
} 
alan gruplara kıyasla işletmeyi güven boyutunda daha kaliteli algıladıkları görülmüştür [Ort. Fark: 0,58150, Sig.: 0,04].

Tablo 10. Eğitim Düzeyi İtibariyle ANOVA Sonuçları

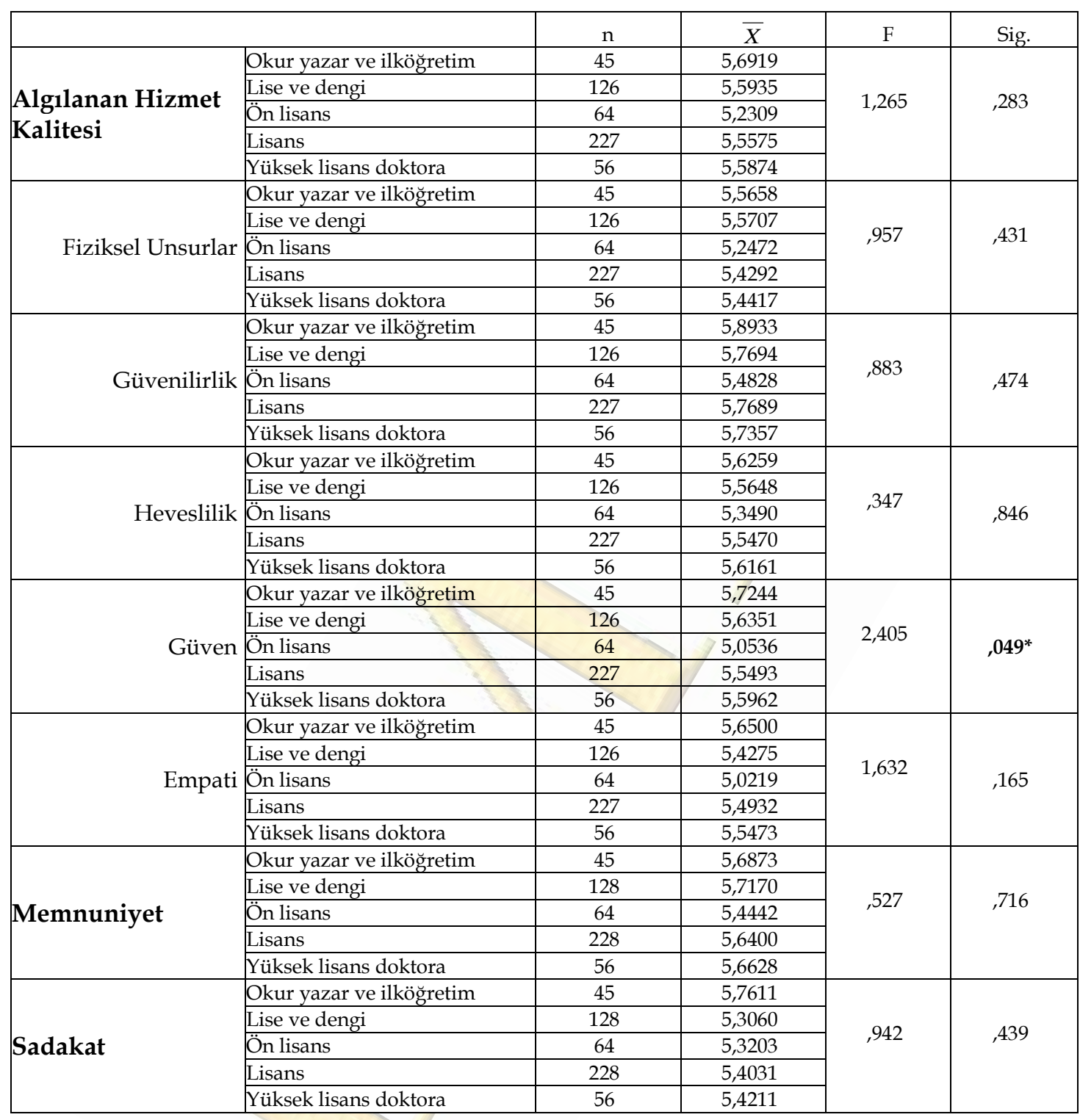

Tablo 11'de çalışma durumu itibariyle katılımcıların yanıtlarında farklılaşma olup olmadığına dair ANOVA sonuçları yer almaktadır. Buna göre, memnuniyet ve sadakat için verilen cevaplarda gruplar arasında anlamlı fark olduğu, hizmet kalitesi açısından ise olmadığı görülmüştür. Dolayısıyla $\mathrm{H}_{7 \mathrm{a}}$ hipotezi reddedilmiş, $\mathrm{H}_{7 \mathrm{~b}}$ ve $\mathrm{H}_{7 \mathrm{c}}$ hipotezleri kabul edilmiştir. Ayrıca algılanan hizmet kalitesinin alt boyutu olan “güven” açısından da gruplar arasında farklılık olduğu bulunmuştur. 
Tablo 11. Çalışma Durumu İtibariyle ANOVA Sonuçları

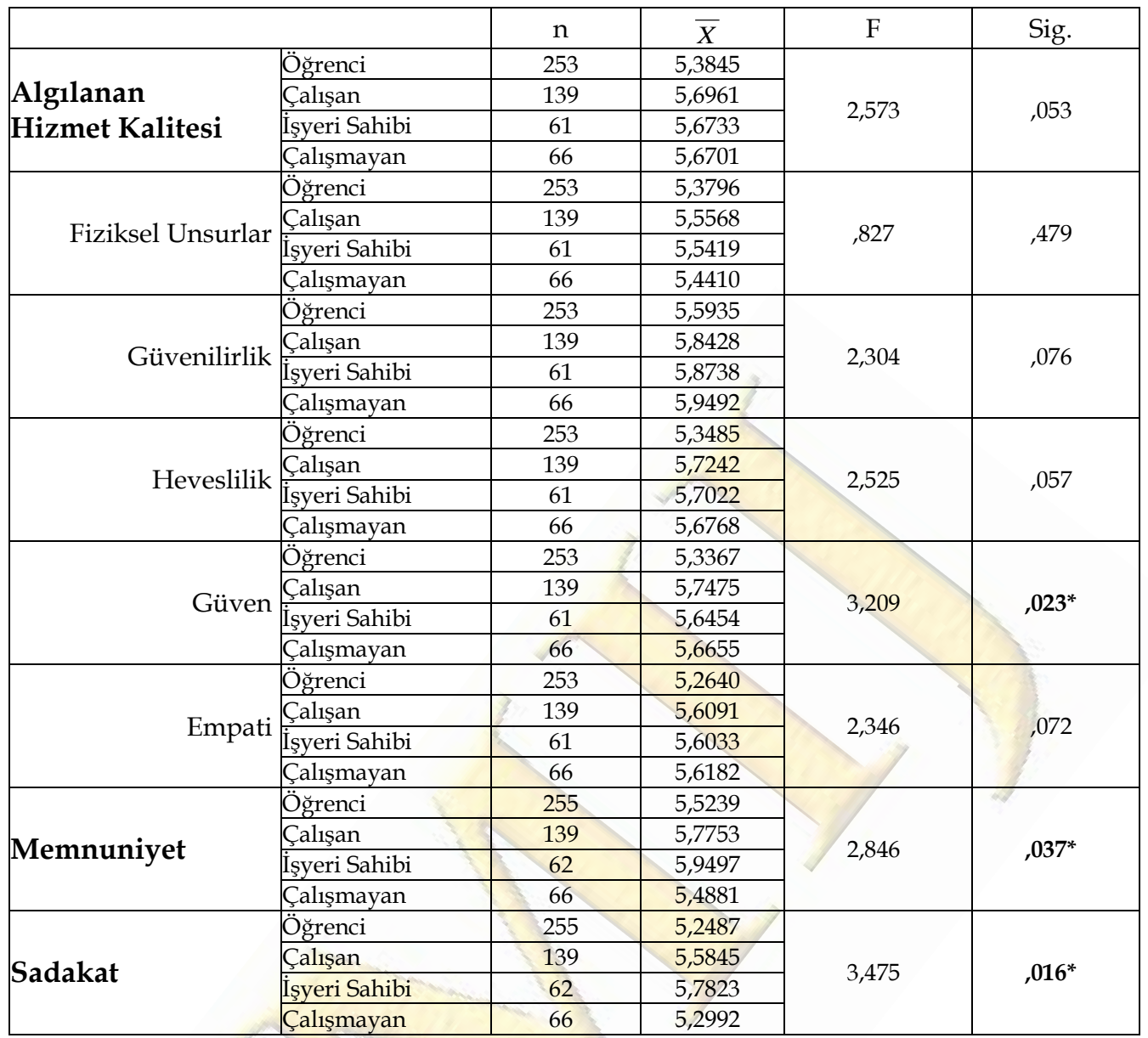

Tablo 11'deki farklılıkların hangi gruplar arasında olduğunu görmek için yapılan Tukey-Kramer Post Hoc testi sonuçlarına göre öğrenci grubunun (Ort.: 5,52), işyeri sahibi olan gruba kıyasla işletmeden memnuniyet düzeylerinin daha düşük olduğu [Ort. Fark: -0,42577, Sig.: 0,07]; yine öğrenci grubunun işletmeye karş1 duydukları sadakatin (Ort.: 5,24) işyeri sahibi olan gruba kıyasla daha düşük olduğu görülmüştür [Ort. Fark: -0,53357, Sig.: 0,03]. Hizmet kalitesinin güven boyutunda ise fark öğrenci olanlar ile bir işte çalışmakta olan kesimler arasındadır. Öğrenci grubunun güven boyutunda kalite algısının (Ort.: 5,33) çalışan gruba kıyasla daha düşük olduğu görülmüştür [Ort. Fark: -0,41077, Sig.: 0,02].

Tablo 12'de gelir itibariyle katılımcıların yanıtlarında farklılaşma olup olmadığına dair ANOVA sonuçları yer almaktadır. Tabloya göre katılımcıların hizmet kalitesine dair algıları, memnuniyet ve sadakat düzeyleri, gelir itibariyle gruplar arasında anlamlı olarak farklılaşmaktadır. Dolayısıyla $\mathrm{H}_{8 \mathrm{a}}, \mathrm{H}_{8 \mathrm{~b}}$ ve $\mathrm{H}_{8 \mathrm{c}}$ hipotezleri kabul edilmiştir. 
Tablo 12. Gelir İtibariyle ANOVA Sonuçları

\begin{tabular}{|c|c|c|c|c|c|}
\hline & & $\mathrm{n}$ & $\bar{X}$ & F. & Sig. \\
\hline \multirow{3}{*}{ Algılanan Hizmet Kalitesi } & $0-2500 \mathrm{TL}$ & 249 & 5,3256 & \multirow{3}{*}{5,946} & \multirow{3}{*}{,003* } \\
\hline & $2501-5000 \mathrm{TL}$ & 100 & 5,5479 & & \\
\hline & 5001 TL üstü & 84 & 5,8567 & & \\
\hline \multirow{3}{*}{ Fiziksel Unsurlar } & $0-2500 \mathrm{TL}$ & 249 & 5,2884 & \multirow{3}{*}{4,003} & \multirow{3}{*}{, $019 *$} \\
\hline & $2501-5000 \mathrm{TL}$ & 100 & 5,3595 & & \\
\hline & 5001 TL üstü & 84 & 5,7030 & & \\
\hline \multirow{3}{*}{ Güvenilirlik } & $0-2500 \mathrm{TL}$ & 249 & 5,5392 & \multirow{3}{*}{3,441} & \multirow{3}{*}{, $033^{*}$} \\
\hline & $2501-5000 \mathrm{TL}$ & 100 & 5,8178 & & \\
\hline & 5001 TL üstü & 84 & 5,9083 & & \\
\hline \multirow{3}{*}{ Heveslilik } & $0-2500 \mathrm{TL}$ & 249 & 5,3126 & \multirow{3}{*}{4,628} & \multirow{3}{*}{, $010^{*}$} \\
\hline & $2501-5000 \mathrm{TL}$ & 100 & 5,5817 & & \\
\hline & 5001 TL üstü & 84 & 5,8750 & & \\
\hline \multirow{3}{*}{ Güven } & $0-2500 \mathrm{TL}$ & 249 & 5,2865 & \multirow{3}{*}{6,129} & \multirow{3}{*}{, $002 *$} \\
\hline & $2501-5000 \mathrm{TL}$ & 100 & 5,5321 & & \\
\hline & 5001 TL üstü & 84 & 5,8846 & & \\
\hline \multirow{3}{*}{ Empati } & $0-2500 \mathrm{TL}$ & 249 & 5,2014 & \multirow{3}{*}{7,219} & \multirow{3}{*}{, $001^{*}$} \\
\hline & $2501-5000 \mathrm{TL}$ & 100 & 5,4483 & & \\
\hline & 5001 TLüstü & 84 & 5,9125 & & \\
\hline \multirow{3}{*}{ Memnuniyet } & $0-2500 \mathrm{TL}$ & 251 & 5,4522 & \multirow{3}{*}{7,469} & \multirow{3}{*}{, $001^{*}$} \\
\hline & $2501-5000 \mathrm{TL}$ & 100 & 5,5940 & & \\
\hline & 5001 TL üstü & 85 & 6,0554 & & \\
\hline \multirow{3}{*}{ Sadakat } & $0-2500 \mathrm{TL}$ & 251 & 5,2387 & \multirow{3}{*}{3,409} & \multirow{3}{*}{, $034^{*}$} \\
\hline & $2501-5000 \mathrm{TL}$ & 100 & 5,4817 & & \\
\hline & 5001 TL üstü & 85 & 5,6794 & & \\
\hline
\end{tabular}

Tablo 12'de gösterilen sonuçlardan hareketle, farklılıkların hangi gruplar arasında olduğunu tespit etmek üzere yapılan Tukey-Kramer Post Hoc testi bulgularına göre işletmeye yönelik hizmet kalitesi algısının 5001 TL ve üstü gelir grubundaki katılımcılarda (Ort.: 5,85), 2500 TL ve altı gelir grubundakilere kıyasla anlamlı olarak yüksek olduğu görülmüştür [Ort. Fark: 0,53108, Sig.: 0,00]. 5001 TL ve üstü gelir grubundaki katılımcıların memnuniyet düzeylerinin (Ort.: 6,05) ise, hem 2501-5000 TL gelir aralığında olan katılımcılara kıyasla [Ort. Fark: 0,46136, Sig.: 0,03], hem de 2500 TL ve altı gelir grubundakilere göre [Ort. Fark: 0,60321, Sig.: 0,00] daha yüksek olduğu görülmüştür. İşletmeye duyulan sadakatin ise 5001 TL ve üstü gelir grubundaki katılımcılarda (Ort.: 5,67), 2500 TL ve altı gelir grubundakilere göre anlamlı olarak yüksek olduğu bulunmuştur [Ort. Fark: 0,44070, Sig.: 0,03].

Tablo 12' de hizmet kalitesinin alt boyutlarındaki değerlendirmelerin de gruplar arasında farklılaştı̆̆ı görülmektedir. Tukey-Kramer Post Hoc testi sonuçlarına göre, “fiziksel unsurlara" yönelik kalite algısının, 5001 TL ve üstü gelir grubundaki katılımcılarda (Ort.: 5,70), 2500 TL ve altı gelir grubundakilere kıyasla anlamlı olarak yüksek olduğu görülmüştür [Ort. Fark: 0,41464, Sig.: 0,01]. “Güvenilirlik” boyutunda hizmet kalitesine yönelik algının ise, 5001 TL ve üstü gelir grubundaki katılımcılarda 
(Ort.: 5,90), 2500 TL ve altı gelir grubundakilere kıyasla anlamlı olarak yüksek olduğu görülmüştür [Ort. Fark: 0,36911, Sig.: 0,05]. “Heveslilik” boyutunda hizmet kalitesine yönelik algının, 5001 TL ve üstü gelir grubundaki katılımcılarda (Ort.: 5,87), 2500 TL ve altı gelir grubundakilere kıyasla anlamlı olarak yüksek olduğu görülmüştür [Ort. Fark: 0,56242, Sig.: 0,00]. “Güven" boyutunda hizmet kalitesine yönelik algının ise, 5001 TL ve üstü gelir grubundaki katılımcılarda (Ort.: 5,88), 2500 TL ve altı gelir grubundakilere kıyasla anlamlı olarak yüksek olduğu görülmüştür [Ort. Fark: 0,59813, Sig.: 0,00]. Son olarak "empati" boyutunda hizmet kalitesine yönelik algının, 5001 TL ve üstü gelir grubundaki katılımcılarda (Ort.: 5,91), 2500 TL ve altı gelir grubundakilere kıyasla anlamlı olarak yüksek olduğu görülmüştür [Ort. Fark: 0,71109, Sig.: 0,01].

Çalışmada son olarak katılımcıların hizmet kalitesi algılarının, memnuniyetlerinin ve sadakatlerinin, -ilk defa gelenler, daha önce birkaç kez gelmiş olanlar ve müdavimler bağlamında- işletmeyi deneyimleme düzeylerine ve -yemeiçme, sosyalleşme ve yalnız kalma bağlamında- işletmeye geliş amaçlarına göre farklılaşıp farklılaşmadığı incelenmiştir. Tablo 13'te işletmeleri deneyimleme düzeyine göre yapılan ANOVA bulguları yer almaktadır. Buna göre katılımcıların hizmet kalitesine dair algıları, memnuniyet ve sadakat düzeyleri, deneyim düzeylerine göre anlamlı olarak farklılaşmaktadır. Dolayısıyla $\mathrm{H}_{9 a}, \mathrm{H}_{9 b}$ ve $\mathrm{H}_{9 c}$ hipotezleri kabul edilmiştir. Tablo 13'te görülen farklılıkların hangi gruplar arasında olduğunu tespit etmek üzere yapılan Scheffe testi bulgularına göre müdavimlerde işletmeye yönelik hizmet kalitesi algısının (Ort.: 5,88), işletmeye ilk kez gelenlere [Ort. Fark: 0,71773, Sig.: 0,02] ve işletmeye daha önce birkaç kez gelmiş olanlara [Ort. Fark: 0,60586, Sig.: 0,00] kıyasla anlamlı olarak yüksek olduğu bulunmuştur. Müdavimlerin memnuniyet düzeylerinin de (Ort.: 5,98), hem işletmeye ilk kez gelenlere [Ort Fark: 0,99653, Sig.: 0,00] hem de daha önce birkaç kez geldiğini belirtenlere göre [Ort. Fark: 0,56479, Sig.: 0,00] daha yüksek olduğu görülmüştür. İşletmeye duyulan sadakat ise tüm gruplar arasında farklılık göstermektedir. Müşteri sadakati müdavimlerde (Ort.: 5,85), ilk kez gelenlere göre [Ort Fark: 1,44111, Sig.: 0,00] ve daha önce birkaç kez geldiğini belirtenlere göre [Ort. Fark: 0,70483, Sig.: 0,00] anlamlı olarak yüksektir; aynı 
zamanda mekana daha önce birkaç kez gelmiş olanların sadakati de (Ort.: 5,14) ilk kez gelenlere göre [Ort Fark: 0,73628, Sig.: 0,00] anlamlı olarak yüksektir.

Tablo 13. İşletmeyi Deneyimleme Düzeyi-ANOVA Sonuçları

\begin{tabular}{|c|c|c|c|c|c|}
\hline & & $\mathrm{n}$ & $\bar{X}$ & $\mathrm{~F}$ & Sig. \\
\hline \multirow{3}{*}{ Algılanan Hizmet Kalitesi } & İlk kez gelenler & 41 & 5,1537 & \multirow{3}{*}{17,362} & \multirow{3}{*}{,000 } \\
\hline & Birkaç kez gelmiş olanlar & 238 & 5,2655 & & \\
\hline & Müdavimler & 238 & 5,8714 & & \\
\hline \multirow{3}{*}{ Fiziksel Unsurlar } & îlk kez gelenler & 41 & 5,2252 & \multirow{3}{*}{13,561} & \multirow{3}{*}{,000 } \\
\hline & Birkaç kez gelmiş olanlar & 238 & 5,2071 & & \\
\hline & Müdavimler & 238 & 5,7324 & & \\
\hline \multirow{3}{*}{ Güvenilirlik } & İlk kez gelenler & 41 & 5,4354 & \multirow{3}{*}{15,402} & \multirow{3}{*}{,000 } \\
\hline & Birkaç kez gelmiş olanlar & 238 & 5,4625 & & \\
\hline & Müdavimler & 238 & 6,0602 & & \\
\hline \multirow{3}{*}{ Heveslilik } & İlk kez gelenler & 41 & 5,1992 & \multirow{3}{*}{9,911} & \multirow{3}{*}{, 000 } \\
\hline & Birkaç kez gelmiş olanlar & 238 & 5,2745 & & \\
\hline & Müdavimler & 238 & 5,8410 & & \\
\hline \multirow{3}{*}{ Güven } & İlk kez gelenler & 41 & 5,0854 & \multirow{3}{*}{15,302} & \multirow{3}{*}{,000 } \\
\hline & Birkaç kez gelmiş olanlar & 238 & 5,2478 & & \\
\hline & Müdavimler & 238 & 5,8737 & & \\
\hline \multirow{3}{*}{ Empati } & İlk kez gelenler & 41 & 4,8232 & \multirow{3}{*}{18,592} & \multirow{3}{*}{,000 } \\
\hline & Birkaç kez gelmiş olanlar & 238 & 5,1357 & & \\
\hline & Müdavimler & 238 & 5,8496 & & \\
\hline \multirow{3}{*}{ Memnuniyet } & İlk kez gelenler & 44 & 4,9864 & \multirow{3}{*}{19,685} & \multirow{3}{*}{, 000} \\
\hline & Birkaç kez gelmiş olanlar & 238 & 5,4181 & & \\
\hline & Müdavimler & 238 & 5,9829 & & \\
\hline \multirow{3}{*}{ Sadakat } & İlk kez gelenler & 44 & 4,4129 & \multirow{3}{*}{30,097} & \multirow{3}{*}{, 000} \\
\hline & Birkaç kez gelmiş olanlar & 238 & 5,1492 & & \\
\hline & Müdavimler & 238 & 5,8540 & & \\
\hline
\end{tabular}

Talo 13'te hizmet kalitesinin alt boyutlarında görülen farklılığın hangi gruplar arasında olduğunu tespit etmek üzere yapılan Scheffe testi sonuçlarına göre, boyutların tamamı açısından kalite algısının müdavimlerde diğer iki gruba kıyasla anlamlı olarak yüksek olduğu bulunmuştur. Müdavimlerde fiziksel unsurlar boyutunda kalitesi algısının (Ort.: 5,73), işletmeye ilk kez gelenlere [Ort. Fark: 0,50715, Sig.: 0,03] ve işletmeye daha önce birkaç kez gelmiş olanlara [Ort. Fark: 0,52522, Sig.: 0,00] kıyasla; güvenilirlik boyutunda kalite algısının müdavimlerde (Ort.: 6,06), işletmeye ilk kez gelenlere [Ort. Fark: 0,62486, Sig.: 0,01] ve işletmeye daha önce birkaç kez gelmiş olanlara [Ort. Fark: 0,59769, Sig.: 0,00] kıyasla; heveslilik boyutunda kalite algısının müdavimlerde (Ort.: 5,84), işletmeye ilk kez gelenlere [Ort. Fark: 0,64185, Sig.: 0,03] ve işletmeye daha önce birkaç kez gelmiş olanlara [Ort. Fark: 0,56653, Sig.: 0,00] kıyasla; güven boyutunda kalite algısının müdavimlerde (Ort.: 5,87), işletmeye ilk kez gelenlere [Ort. Fark: 0,78833, Sig.: 0,00] ve işletmeye daha önce birkaç kez gelmiş olanlara [Ort. Fark: 0,62594, Sig.: 0,00] kiyasla ve son olarak empati boyutunda kalite algısının yine müdavimlerde (Ort.: 5,84), işletmeye ilk kez gelenlere [Ort. Fark: 1,02648, 
Sig.: 0,00] ve işletmeye daha önce birkaç kez gelmiş olanlara [Ort. Fark: 0,71394, Sig.: 0,00] kıyasla anlamlı olarak yüksek olduğu görülmüştür.

Tablo 14 'te işletmeye geliş amaçlarına göre katılımcıların yanıtlarında farklılaşma olup olmadığına dair yapılan ANOVA sonuçları yer almaktadır. Bu analiz için, daha önce Tablo 2' de sunulan yedi amaç ifadesinden "kahve içmek" ve "menü" seçenekleri "yeme-içme", "arkadaşlarla vakit geçirmek", "yeni insanlarla tanışmak", “aileyle vakit geçirmek" ve "eğlenmek" seçenekleri "sosyalleşme" ve "sükunet, huzur bulmak, kafa dinlemek" seçeneği "yalnız kalma" kategorileri altında birleştirilmiştir. ${ }^{9}$

Tablo 14. İşletmeye Geliş Amac1-ANOVA Sonuçları

\begin{tabular}{|c|c|c|c|c|c|}
\hline & & $\mathrm{n}$ & $\bar{X}$ & $\mathrm{~F}$ & Sig. \\
\hline \multirow{3}{*}{ Algılanan Hizmet Kalitesi } & Yeme-içme amaçlı & 215 & 5,5595 & \multirow{3}{*}{2,555} & \multirow{3}{*}{,079 } \\
\hline & Yalnız kalma amaçlı & 41 & 5,8448 & & \\
\hline & Sosyalleşme amaçlı & 185 & 5,3903 & & \\
\hline \multirow{3}{*}{ Fiziksel Unsurlar } & Yeme-içme amaçlı & 215 & 5,4333 & \multirow{3}{*}{1,948} & \multirow{3}{*}{ 144 } \\
\hline & Yalnız kalma amaçlı & 41 & 5,7238 & & \\
\hline & Sosyalleşme amaçlı & 185 & 5,3316 & & \\
\hline \multirow{3}{*}{ Güvenilirlik } & Yeme-içme amaçlı & 215 & 5,7373 & \multirow{3}{*}{2,624} & \multirow{3}{*}{074} \\
\hline & Yalnız kalma amaçlı & 41 & 6,1085 & & \\
\hline & Sosyalleşme amaçlı & 185 & 5,6102 & & \\
\hline \multirow{3}{*}{ Heveslilik } & Yeme-içme amaçlı & 215 & 5,5395 & \multirow{3}{*}{846} & \multirow{3}{*}{430} \\
\hline & Yalnız kalma amaçlı & 41 & 5,7561 & & \\
\hline & Sosyalleşme amaçlı & 185 & 5,4315 & & \\
\hline \multirow{3}{*}{ Güven } & Yeme-içme amaçlı & 215 & 5,5540 & \multirow{3}{*}{2,696} & \multirow{3}{*}{, 069} \\
\hline & Yalnız kalma amaçlı & 41 & 5,8848 & & \\
\hline & Sosyalleşme amaçlı & 185 & 5,3666 & & \\
\hline \multirow{3}{*}{ Empati } & Yeme-içme amaçlı & 215 & 5,5335 & \multirow{3}{*}{3,472} & \multirow{3}{*}{, $032^{*}$} \\
\hline & Yalnız kalma amaçlı & 41 & 5,7508 & & \\
\hline & Sosyalleşme amaçlı & 185 & 5,2118 & & \\
\hline \multirow{3}{*}{ Memnuniyet } & Yeme-içme amaçlı & 215 & 5,6969 & \multirow{3}{*}{1,210} & \multirow{3}{*}{ 299 } \\
\hline & Yalnız kalma amaçlı & 41 & 5,6852 & & \\
\hline & Sosyalleşme amaçlı & 187 & 5,5026 & & \\
\hline \multirow{3}{*}{ Sadakat } & Yeme-içme amaçlı & 215 & 5,4403 & \multirow{3}{*}{1,092} & \multirow{3}{*}{,336 } \\
\hline & Yalnız kalma amaçlı & 41 & 5,6098 & & \\
\hline & Sosyalleşme amaçlı & 187 & 5,2888 & & \\
\hline
\end{tabular}

Tablo 14'e göre, katılımcıların hizmet kalitesine dair algıları ile memnuniyet ve sadakat düzeyleri, işletmeye geliş amaçlarına göre anlamlı olarak farklılaşmamaktadır. Dolayısıyla $\mathrm{H}_{10 a}, \mathrm{H}_{10 \mathrm{~b}}$ ve $\mathrm{H}_{10 \mathrm{c}}$ hipotezleri reddedilmiştir. Tabloda yalnızca hizmet kalitesinin alt boyutu olan empati açısından katılımcıların algılarının gruplar arasında anlamlı olarak farklılaştı̆̆ı görülmüştür. Tukey-Kramer Post Hoc

\footnotetext{
${ }^{9}$ Birleştirme sonucunda Tablo 2 ile Tablo 14 arasında n gözlem sayıları arasında görülen fark, yöntem bölümünde ve dipnot $6^{\prime}$ da belirtildiği gibi seçeneklere "deneyimlemedim/fikrim yok" seçeneği tanımlanmasından ve ilave olarak katılımcıya her soruya cevap verme zorunluluğu tanımlanmamış olmasından kaynaklanmaktadır.
} 
testi sonucuna göre işletmeye sosyalleşme amaçlı gelen katılımcılarda empati alt boyutunda kalite algısının (Ort.: 5,75), yeme içme amaçlı gelenlere [Ort. fark: 0,32169, Sig.: 0,07] ve yalnız kalma amaçlı gelenlere [Ort. fark: 0,53901, Sig.: 0,09] göre anlamlı olarak yüksek olduğu görülmüştür.

\section{SONUÇ}

Yiyecek-içecek işletmelerinde algılanan hizmet kalitesinin müşteri memnuniyeti ve sadakati üzerine etkisini ve ayrıca müşteri memnuniyetinin sadakati açıklama durumunu inceleyen bu çalışma, ulusal bir kahve zinciri şubesinde 2019 Aralık ayında gerçekleştirilmiştir. Sonuç olarak araştırma katılımcılarının işletmenin hizmet kalitesine yönelik algılarının hem memnuniyetlerini hem de sadakatlerini, memnuniyetlerinin ise yine sadakatlerini pozitif yönde anlamlı olarak etkilediği bulunmuştur. Bu bulguların literatürle uyumlu olduğu görülmektedir (Örn. Bilgin, 2017; Aksu ve diğerleri, 2016; Diab ve diğerleri, 2016; Bekar ve Kılıç, 2015; Haghigi ve diğerleri, 2012; Ha ve Jang, 2010). Ancak müşteri memnuniyeti bağımlı değişkeninde açıklanan varyansın müşteri sadakatinde açıklanan varyanstan daha fazla olduğunu ifade etmek gerekir. Araştırma katılımcılarının hizmet kalitesi algılarının yüksek olmasına rağmen, bu algıların sadakati müşteri memnuniyetine kıyasla daha az açıklıyor oluşu bulgusunun önemli olduğu düşünülmektedir. Burada işletme açısından, sadakatin hizmet kalitesi haricindeki açıklayıcılarını belirleme ve bu unsurları da dikkate alma ihtiyacı doğmaktadır.

Hizmet kalitesinin alt boyutları itibariyle yapılan incelemede ise, fiziksel unsurlar, güven ve empati boyutlarının hem müşteri memnuniyetini hem de sadakatini pozitif yönde anlamlı etkilediği, güvenilirlik ve heveslilik boyutlarının ise bu değişkenler üzerindeki etkisinin istatistiksel olarak anlamlı olmadığı bulunmuştur. Literatürde alt boyutların söz konusu değişkenlere etkileri üzerine bulgular farklılıklar göstermektedir. Örneğin Aksu ve diğerlerinin çalışmasında (2016) güvenirlik [güvenilirlik] ve güvence [güven] boyutlarının müşteri memnuniyetini pozitif yönde etkilediği, empati ve fiziksel unsur boyutlarının ise memnuniyet üzerinde anlamlı bir etkisinin olmadığı bulunmuştur. Yine yiyecek-içecek işletmelerinde yapılan başka bir araştırmada heveslilik boyutunun müşteri memnuniyetine etkisi ön plana çıkmıştır 
(Andaleeb ve Conway, 2006). Chen'in (2016) çalışmasında ise güven boyutunun müşteri sadakati üzerinde etkisinin olduğu bulunmuştur. Hizmetler alanı son derece heterojen bir alan olduğundan, her analiz biriminde yani incelenen işletmede hem hizmet kalitesi unsurlarına ilişkin pratik, hem de müşterilerin algıları değişiklik gösterebileceğinden, literatürde farklı sonuçların görülmesi doğaldır.

Mevcut çalışma belirli bir işletmenin müşterileriyle yapıldığından, işletme açısından söz konusu alt boyutlarda ortaya çıkan tablonun değerlendirilmesi zorunluluğu ortaya çıkmaktadır. Hansen' in de belirttiği gibi (2014, s. 120), DINESERV gibi ölçümler yiyecek-içecek işletmelerinin sahip ve yöneticilerine işletmelerinin hizmet kalitesi hakkında bilgi sağlarken, atılması gereken adımlar hakkında da onlara fikir verir. Bu sebeple, ilgili işletme özelinde olmak kaydıyla, bir yandan fiziksel unsurlar, güven ve empati boyutlarında müşteri algısının memnuniyet ve sadakate etki etmekte olduğu bilgisinden hareketle işletmenin söz konusu üç boyuttaki çalışmalarında sürdürülebilir bir kalite sağlayabilmesi önemli olmakta; diğer yandan güvenilirlik ve heveslilik açısından memnuniyet ve sadakate etki etmeyen hizmet unsurlarının gözden geçirilerek etki edebilecek şekilde yeniden tasarlanması gerekmektedir. Ayrıca Wilson, Zeithaml, Bitner ve Gremler (2016) hizmet performansının, çalışanlarla ilgili heterojenlik nedeniyle sürekli izlenmesi gereken bir konu olduğunun altını çizmektedir. Kırcova ve diğerleri de (2020, s. 81) hizmetlerin her defasında- yeniden aynı şekilde sunulmasının zorluğuna işaret etmektedir. Dolayısıyla bir kerelik ölçümlerler değil, periyodik çalışmalarla hizmet kalitesinin takip edilmesi ve sürdürülebilirliğin sağlanması gerekmektedir.

Çalışmada ayrıca katılımcıların hizmet kalitesi algılarının, memnuniyet düzeylerinin ve sadakat durumlarının demografik değişkenler itibariyle farklılık gösterip göstermediğine yönelik ilave incelemeler de yapılmıştır. Bulgularda, hizmet kalitesi algısının kadınlarda erkeklere göre anlamlı olarak yüksek olduğu, müşteri memnuniyeti ve sadakati açısından ise gruplar arasında anlamlı bir farklılık olmadığı; çalışma durumları itibariyle hizmet kalitesi algılarında gruplar arasında anlamlı farklılığın bulunmadığı, ancak öğrenci grubuna kıyasla kendi işinin sahibi olan kesimlerin memnuniyetlerinin ve sadakatlerinin yüksek olduğu; gelir itibariyle ise yüksek gelire sahip olanların daha düşük gelire sahip olanlara kıyasla hem hizmet 
kalitesi algılarının, hem de memnuniyetlerinin ve sadakatlerinin yüksek olduğu görülmüştür.

Çalışmada son olarak deneyimlerle ilgili olarak değerlendirebilecek iki analiz yapılmıştır. $\mathrm{Bu}$ analizlerin ilkinde, müşterilerin işletmeyi deneyimleme düzeyi mekâna ilk kez gelenler, daha önce de gelmiş olanlar ve müdavimler bağlamında ele alınıp, bu grupların yanıtlarında farklılaşma olup olmadığı araştırılmıştır. Ele alınan tüm ana değişkenler ve tüm alt boyutlarda müdavimlerin değerlendirmelerinin diğer iki gruba göre anlamlı olarak yüksek olduğu görülmüştür. Bu durumun yorumlanabileceği iki perspektif söz konusudur. Bunlardan birincisi işletmeye yönelik kalite algısı ile işletmeden duydukları memnuniyet yüksek olan ve işletmeyle arasında sadakat ilişkisi oluşmuş bireylerin doğal olarak işletmenin müdavimi haline gelebileceğidir. Bir diğer ifadeyle, bu kişiler iyi bir kalite algısına ve memnuniyet düzeyine sahip olduklarından müdavimdir, dolayısıyla olumlu skorlar vermeleri doğaldır. İkinci perspektif ise sadık müşteri olmakla ilgilidir. Müşterilerin işletmeyle kurduğu ilişki güçlendikçe, işletmenin hatalarını affetme, yaşanan olumsuzlukları görmeme kısaca tolerans eğilimleri de artabilmektedir (Örn. Yagil ve Luria, 2016, Armağan ve Acayıp, 2015). Müdavimlerin sadık müşteriler olduğu varsayımında -ki bu çalışmada zaten müdavimlerin sadakat skoru diğer gruplara göre anlamlı olarak yüksektir-, işletmeyi hizmet kalitesi açısından düşük skorlamasını beklemek pek gerçekçi olmayabilir. Dolayısıyla, bulguları yorumlarken bu iki farklı nedensellik yönüne, dikkat etmek gerekir. Çünkü birinci perspektif işletme açısından pozitif bir durumu göstermekte iken, ikinci perspektif işletmenin her zaman başarılı olduğunu garanti etmemektedir. Villi'nin de belirttiği gibi (2019, s. 60) hizmet sektöründe tamamıyla hatasızlık mümkün değildir. Müşterilerin işletmelere duydukları bağlılık ve sadakat de sarsılmaz değildir. Dolayısıyla sadık müşterilerin/müdavimlerin sürdürülebilirliğinin, işletmenin hizmet kalitesindeki sürdürülebilirliğe ve ayrıca iyi bir müşteri ilişki yönetimine bağlı olduğunu burada not etmekte fayda vardır.

Müşterilerin deneyimleriyle ilgili olarak görülebilecek son analiz, müşterilerin işletmeye geliş amacı bağlamında kurgulanmıştır. Bu analizde, işletmeye sosyalleşme, yeme-içme ya da yalnız kalma amacıyla gelen grupların hizmet kalitesi algıları ile memnuniyet ve sadakat düzeylerinde anlamlı bir farklılı̆̆a rastlanmamıştır. Söz 
konusu grupların işletmede yaşadıkları deneyimler farklılaşabileceğinden, kalite algıları ile memnuniyet ve sadakatlerinin de farklılaşabileceği düşünülebilirdi. Ancak araştırmacılar yalnız kalma amacıyla işletmeyi tercih eden müşterilerin genellikle mekânın az yoğun olan zamanlarını (örn. 10:00, hafta içi gündüz vb.) tercih ettiklerini gözlemlemişlerdir. Sosyalleşme amaçlı gelenler ise söz konusu işletmenin en kalabalık olduğu 20:00'den sonraki zaman diliminde mekâna uğramaktadırlar. Bu durumda her iki grubun da geliş amacıyla bağlantılı olabilecek örneğin sükûnet ya da eğlence beklentileri işletme tarafından karşılanabilmektedir. Dolayısıyla bu bağlamda farklılık oluşmaması normal görülmektedir. Bu konuda elbette başka perspektifler de sunulabilir, dolayısıyla izleyen çalışmalarda kapsam biraz daha genişletilip şekillendirilerek bu konu araştırılabilir.

Son olarak çalışmanın yöntemsel olarak bahsedilmesi gereken bir kısıtı bulunmaktadır ve bu kısıtın araştırma bulgularının yorumlanmasını doğrudan etkileyebileceği düşünülmektedir. Mevcut araştırma söz konusu işletme içerisinde, hizmet sunumu esnasında, müşteriler hizmetlerden yararlanmakta iken yapılmıştır. Bireyin mekânın içerisinde zaten kendi tercihiyle bulunuyor olmasının, etrafında personelin varlığının, deneyimin o anda gerçekleşiyor olmasının [ve diğer unsurların] verilen cevaplara yansıyabileceğini göz ardı etmemek gerekir. Katılımcıların yukarıda bahsedilen tüm değişkenlere verdikleri cevapların ortalama değerlerinin 7'li aralıklı ölçekte 5' in üzerinde olduğunu, yani olumlu olduğunu belirtmek gerekir. Cevapların söz konusu olumluluk düzeylerini, bu hususu dikkate alarak, yani araştırmanın şube içinde müşterilerce deneyim yaşanırken yürütülmüş olduğu kısıtı bilgisiyle birlikte değerlendirmek doğru bir yaklaşım olacaktır. Müşteriler zaten bu olumluluk nedeniyle mi oradalar, yoksa orada oldukları için mi deneyimlerini pozitif değerlemeyi tercih ediyorlar sorusunun ise ayrıca incelenmesi gerekmektedir. Aynı araştırma, söz konusu işletme için hem mekân içinde deneyim yaşamakta olan müşterilerle, hem de mekânsal etkiden arındırılmış olarak mekân dışında ulaşılabilecek müşterilerle çift örneklemli olarak yürütüldüğünde bu konuda daha net bir görünüm elde edilebilecektir. Ayrıca bu çalışmada müşteri memnuniyetinin, algılanan hizmet kalitesi ile müşteri sadakati arasında aracılık rolüne ilişkin bir 
inceleme yapılmamıştır. İzleyen araştırmalarda kurgulanan modellerde aracılık etkilerinin de dikkate alınması önerilmektedir. 


\section{KAYNAKÇA}

Adeinat, I. (2019). Measuring service quality efficiency using DINESERV. International Journal for Quality Research, 13(3), 591-604.

Aksu, M., Korkmaz, H. ve Sünnetçioğlu, S. (2016). Yiyecek ve içecek işletmelerindeki hizmet kalitesinin müşteri memnuniyeti üzerinde etkisi: Bozcaada'da DINESERV modeliyle bir araştırma. Balkesir University The Journal of Social Sciences Institute, 19(35), 1-18.

Andaleeb, S. S. ve Conway, C. (2006). Customer satisfaction in the restaurant industry: An examination of the transaction-specific model. Journal of Services Marketing, 20(1), 3-11.

Armağan, E ve Acayıp, E. (2015). Alı̧veriş merkezlerindeki müşteri hizmetleri uygulamalarının müşteri sadakatine etkisi: Eskişehir ilinde uygulama. EKEV Akademi Dergisi, 19(62), 1-20.

Aydoğdu, A., Yaşarsoy, E. ve Dilsiz, T. (2019). Yiyecek içecek işletmelerinde hizmet kalitesi ve tüketici doyumu: Kastamonu örneği. Journal of Tourism Theory and Research, 5(2), 155-170.

Barber, N., Goodman R. J. ve Goh, B. K. (2011). Restaurant consumers repeat patronage: A service quality concern. International Journal of Hospitality Management, 30, 329-336.

Bayuk, M. N. (2006). Hizmet pazarlaması ve müşteri tutma. Akademik Bakış Dergisi, 10, 1-12.

Bekar, A. ve Kılıç, B. (2015). Hizmet kalitesi memnuniyet ilişkisi: Üniversite kampüsünde faaliyet gösteren yiyecek içecek işletmelerinde karşılaştırılmalı bir uygulama. Sosyal ve Beşeri Bilimler Araştırmaları Dergisi, (34), 1-24

Bilgin, Y. (2017). Restoran işletmelerinde hizmet kalitesi, müşteri memnuniyeti ve müşteri sadakatinin ağızdan ağıza pazarlamaya etkisi. İşletme Araştırmaları Dergisi, 9(4), 33-62.

Bulgan, G. (2010). Otel müşterilerinin yüksek ve düşük sezonda hizmet beklentileri ve memnuniyet düzeylerinin değerlendirilmesi: Antalya Belek'te bir araştırma. (Yayınlanmamış Yüksek Lisans Tezi), Afyon Kocatepe Üniversitesi.

Büyükuysal, M. Ç. ve Öz, İ. İ. (2016). Çoklu doğrusal bağıntı varlığında en küçük karelere alternatif yaklaşım: Ridge regresyon. Düzce Üniversitesi Sağllk Bilimleri Enstitüsü Dergisi, 6(2), 110-114.

Chaudhuri, A. ve Holbrook, M. B. (2001). The chain of effects from brand trust and brand affect to brand performance: The role of brand loyalty. Journal of Marketing, 65(2), 81-93.

Chen, C. T., Cheng, C. C. ve Hsu, F. S. (2013). GRSERV Scale: An effective tool for measuring consumer perceptions of service quality in green restaurants. Total Quality Management \& Business Excellence, 26(34), 355-367.

Chen, J. L. (2016). The relationship among service quality, relationship quality and customer loyalty for chain restaurant industry. International Journal of Marketing Studies, 8(3), 33-42.

Chen, S. C. (2012). Fuzzy cognitive map for optimizing solutions for retaining full-service restaurant customer. Procedia - Social and Behavioral Sciences, 57, 47-52.

Chun, S. ve Nyam-Ochir, A. (2020). The effects of fast food restaurant attributes on customer satisfaction, revisit intention, and recommendation using DINESERV scale. Sustainability, 12(18), 1-19. 
Cronin, J. J. Jr ve Taylor, S. A. (1992). Measuring services quality. Journal of Marketing, 56(3), 55-68.

Çiğdemli, A. Ö. Ö. ve İştin, A. E. (2018). Restoranlarda müşteri hizmet kalitesi algısının DINESERV modeli ile değerlendirilmesi: Şırnak örneği. Organizasyon ve Yönetim Bilimleri Dergisi, 10(2), 17-30.

Çoban, S. ve Demirhan, M. (2019). Mobil Bankacılıkta algılanan deneyimsel değer ve davranışsal etkileri: Nevşehir ili örneği. Business \& Management Studies: An International Journal, 7(1), 78-101.

Diab, D. M. E., Mohammed, H. E., Mansour, E. H. ve Saad O. (2016). Investigating the impact of key dimensions of service quality on customers' satisfaction and loyalty: Evidences from the restaurant industry in Sudan. Marketing and Branding Research, 3(2), 153-165.

Ha, J. ve Jang, S. S. (2010). Effects of service quality and food quality: The moderating role of atmospherics in an ethnic restaurant segment. International Journal of Hospitality Management, 29, 520529.

Haghighi, M., Dorosti, A., Rahnama, A. ve Hoseinpour, A. (2012). Evaluation of factors affecting customer loyalty in the restaurant industry. African Journal of Business Management, 6(14), 5039-5046.

Hansen, K. V. (2014). Development of SERVQUAL and DINESERV for measuring meal experiences in eating establishments. Scandinavian Journal of Hospitality and Tourism, 14(2), 116-134.

Hyun, S. S. (2010). Predictors of relationship quality and loyalty in the chain restaurant industry. Cornell Hospitality Quarterly, 51(2), 251-267.

IBM (ty). Does SPSS offer Tukey-Kramer post-hoc tests?, IBM Support. Erişim Adresi: https://www.ibm.com/support/pages/does-spss-offer-tukey-kramer-post-hoc-tests, Erişim Tarihi: 14.12.2020.

İlhan, İ. ve K1liçhan, R. (2016). Kruvaziyer gemilerin yiyecek içecek departmanlarında hizmet kalitesi, müşteri memnuniyeti ve müşteri sadakati ilişkileri: Ketchikan, Juneau ve Skagway limanlarında bir araştırma. Nevşehir Hacı Bektaş Veli Üniversitesi SBE Dergisi, 6(1) 65-83.

Kılıç, B. ve Kurnaz, A. (2012). Yiyecek içecek işletmelerinde hizmet kalitesinin DINESERV modeli ile ölçümü. Finans Politik \& Ekonomik Yorumlar, 49(564), 87-104.

Kılıçhan, R. ve Ülker, M. (2015). Fast food restoranlarının hizmet kalitesinin DINESERV modeli ile ölçülmesi: Kayseri ili örneği. 16. Ulusal Turizm Kongresi Bildiriler Kitabı (s. 885-904) içinde, Ankara: Detay Yayincilik.

Kırcova, İ., Köse, G. ve Özer, E. Ece. (2020). Şehirde yolculuk: Algilanan hizmet kalitesi, kurum imaji, müşteri memnuniyeti ve müşteri sadakati ilişkisinde şehir hatları örneği. Uluslararası İktisadi ve İdari Incelemeler Dergisi, (28), 79-100.

Kim, K. ve Choi, K. (2019). Bridging the perception gap between management and customers on DINESERV attributes: The Korean all-you-can-eat buffet. Sustainability, 11(19), 1-21.

Kim, W. G., Ng, C. Y. N. ve Kim, Y. (2009). Influence of institutional DINESERV on customer satisfaction, return intention, and word-of mouth. International Journal of Hospitality Management, 28, 1017.

Knutson, B. J., Stevens, P., Patton, C.V. ve Yokohama, F. (1990). Lodgeserv: A service quality index for the lodging industry. Hospitality Research Journal, 14(2), 1-16. 
Koç, F. Kaya, N., Özbek, V. ve Akkılıç, M. E. (2014). Algılanan fiyat ile tüketici güveni arasında algılanan hizmet kalitesinin aracı etkisi: Bankacılık ve GSM Sektörlerinin karşılaştırılmasına yönelik bir araştırma. Pazarlama ve Pazarlama Araştırmaları Dergisi, 13(Ocak), 1-26.

Kramer, C. Y. (1956). Extension of multiple range tests to group means with unequal numbers of replications. Biometrics, 12(3), 307-310.

Kumar, V. ve Shah, D. (2004). Building and sustaining profitable customer loyalty for the 21st century. Journal of Retailing, 80(4), 317-329.

Kurnuç, M., Korucuk, S. ve Küçük, O. (2015). Kalite iyileştirme çalışmalarının müşteri memnuniyeti ve müşteri sadakatine etkisi. The International New Issues In Social Sciences, 1(1), 21-44.

Küçükergin, K. G. ve Uygur, S. M. (2013). Yiyecek-içecek işletmelerinde müşteri sadakati oluşum süreci ve müşteri tatmini ve ataletin bu sürece etkisi. Turar Turizm ve Araştırma Dergisi, 1(2), 4-23.

Martinez, J. A. ve Martinez, L. (2010). Some insights on conceptualizing and measuring service quality. Journal of Retailing and Consumer Services, 17(1), 29-42.

Mei, A. W. O., Dean, A. M. ve White, C. J. (1999). Analysing service quality in the hospitality industry. Managing Service Quality: An International Journal, 9(2), 136-143.

Parasuraman, A., Zeithaml, V. A. ve Berry, L. L. (1985). A conceptual model of service quality and its implications for future research. Journal of Marketing, 49, 41-50.

Parasuraman, A., Zeithaml, V. A. ve Berry, L. L. (1988). SERVQUAL: A multiple-item scale for measuring consumer perceptions of service quality. Journal of Retailing, 64(1), 12- 37.

Stevens, P., Knutson, B., ve Patton, M. (1995). DINESERV: A tool for measuring service quality in restaurants. Cornell Hotel and Restaurant Administration Quarterly, 36(2), 56-60.

Tuncer, İ. (2017). Yiyecek içecek işletmelerinde hizmet kalitesi boyutları ve ölçeklerinin incelenmesi. International Journal of Academic Value Studies, 3(16), 321-329.

Uyar, A. (2019). Müşteri memnuniyeti ile müşteri sadakati arasındaki ilişkinin yapısal eşitlik modeli ile incelenmesi: Otomobil kullanıcıları üzerine bir uygulama. Elektronik Sosyal Bilimler Dergisi, 69(18), 4157.

Villi, B. (2019). Hizmet hatalarıda müşteri katılımının atfetmeye etkisinin duygusal zeka ve içsel kontrol odağı perspektifinden incelenmesi. (Yayınlanmamış Doktora Tezi), Balıkesir Üniversitesi Sosyal Bilimler Enstitüsü.

Wilson, A., Zeithaml, V. A., Bitner, M. J. ve Gremler, D. (2016). Service marketing: Integrating customer focus across the firm (Third European Edition). Berkshire: McGraw-Hill Education.

Yagil, D. ve Luria, G. (2016). Customer forgiveness of unsatisfactory service: Manifestations and antecedents. Service Business, 10, 557-579.

Yangınlar, G. ve Tuna, F. (2020). Havayolu taşımacılığında hizmet kalitesinin kurumsal imaj, müşteri memnuniyeti ve müşteri sadakati üzerindeki etkisi. Journal of Business Research - Turk, 12(1), 173-187. 